\title{
Sales failure: A review and future research directions
}

\author{
Author: Phillip McGowan
}

Title: Senior Teaching Fellow

Institution: University of Portsmouth

Address: Richmond Building, Portland Street, Portsmouth PO1 3DE

Telephone number: +44 (0)2392084 4820

Email address: phillip.mcgowan@port.ac.uk

\section{Keywords:}

sales failure, buyer seller relationships, key account management, sales measurement, sales strategy, sales management

\begin{abstract}
As much as $94 \%$ of all sales effort results in outcomes that can be perceived as denoting failure. This article presents findings from a systematic review of literature which identifies that, to date, no single review article appears to exist that simultaneously and explicitly considers the antecedents and detrimental effects of such sales failure. A total of 36 topics of interest were identified, with recommendations for future research presented for each. A framework for the measurement of overall sales failure is presented that proposes a synergistic relationship between the selling strategy of the firm, management capability to enact strategy through their teams as well as the skills, aptitude, professionalism and psychological factors associated with salespeople, without which the full sales potential of an organisation cannot be met. A discussion and suggestions for future research is then presented.
\end{abstract}




\section{Introduction}

Sales success is critical to overall company performance (Cova, Salle, \& Vincent, 2000; Korschun, 2015). Conversely, failure may mean not only the loss of orders and associated potential revenue and profit, but also the actual time and money spent bidding for the orders (Cova, Salle, \& Vincent, 2000; Korschun, 2015). More sales opportunities are, however, lost than won, with claimed failure rates for selling activity as high as 94\% (Raichshtain, 2014). Failure not only affects the company but may also have personal consequences for salespeople and their managers: "Accounting for sales loss is important to managing the sales force as well as helping to ensure corporate profitability. Indeed, inaccurate explanations [of sales loss] increase the likelihood that subsequent selling effort will prove ineffective" (Mallin \& Mayo, 2006, p. 345). This suggests that academics and practitioners alike will benefit from new insights into this under-researched area and that the availability of causal information to minimise repeated failure would be strategically important (H. Liu, Liu, \& Liu, 2013).

Salespeople themselves, however, accept that failure is an expected part of their job (Fine, 2007; Morris, LaForge, \& Allen, 1994). While failure may be expected at any time in a career, tenure is one significant factor, as the first few years in a selling role may involve more failure than later stages (Fine, 2007; Morris et al., 1994). Failures may include (but are not limited to) the failure to generate sufficient or appropriate sales leads, failure to secure appointments (Mallin \& Mayo, 2006), being unprepared for meetings, not following up or completing actions (Gonzalez, Hoffman, \& Ingram, 2014; Hansen, Lund, \& DeCarlo, 2016; Pullins, Timonen, Kaski, \& Holopainen, 2017), failure to assess customer needs correctly or to make an appropriate proposal (Friend, Curasi, Boles, \& Bellenger, 2014; Pullins et al., 2017), failure to deal with cost or value objections or to negotiate agreements (Friend et al., 2014; Mallin \& Mayo, 2006), failure to close the order or to win the account (Friend et al., 
2014; Mallin \& Mayo, 2006; Verbeke \& Bagozzi, 2000), failure to dislodge an incumbent or to increase the supplier's share of the customer's wallet (Friend et al., 2014; LaForge, Ingram, Hoffman, \& Gonzalez, 2010; Mayo \& Mallin, 2010), failure of long-term relationships (H. Liu et al., 2013), failure caused by post-sale service problems, losing an existing customer (Chia-Chi, 2006; Friend et al., 2014; LaForge et al., 2010), and failure to reacquire lost customers (Elhafsi, Zhi, Camus, \& Craye, 2015; Hansen et al., 2016; Widmier \& Jackson Jr, 2002).

Nevertheless, for some salespeople failure may help them to learn and improve (Dixon \& Schertzer, 2005; Johnson, Friend, Rutherford, \& Hamwi, 2016; Mayo \& Mallin, 2010), implying that short-term failure may assist towards long-term success. For others, however, fear of failure and fear of the consequences of repeated failure can promote reactions and emotions ranging from loss of organisational commitment and reduced productivity, to feelings of stress, anger, grief, loss of confidence and, ultimately, can lead to their departure from the organisation (Elhafsi et al., 2015; Goodwin, Mayo, \& Hill, 1997; Morris et al., 1994). Furthermore, from a business perspective, reduced productivity and sales revenue as well as recruitment and training costs combine to make replacing a salesperson expensive (Richardson, 1999). This also suggests that further investigation to inform academics and practitioners of the causes of sales failure would be a worthwhile endeavour (Andrea L. Dixon, Spiro, \& Forbes, 2003; Dubinsky, 1999; Dubinsky, Jolson, Anderson, \& Mehta, 2001; Gonzalez, Hoffman, \& Ingram, 2005; Johnson, Friend, Rutherford, et al., 2016; Johnston, Hair Jr, Boles, \& Kurtz, 1989; Jolson, 1999; Morris et al., 1994).

Sales scholars have invested significant effort into investigating sales strategy and sales management and how each can be brought to bear to increase the effectiveness of salespeople (Fürst, Leimbach, \& Prigge, 2017; Khusainova, Jong, Lee, Marshall, \& Rudd, 2018; Plank, Reid, Koppitsch, \& Meyer, 2018; Reid, Plank, Peterson, \& Rich, 2017). Yet, there would 
appear to be little literature directed towards detriments, i.e. sales failure (Friend et al., 2014; Gonzalez et al., 2005; Johnson, Friend, Rutherford, et al., 2016; K. Wilson \& Woodburn, 2014). Instead, while it would appear axiomatic that an individual's improvement may deliver a positive impact, achieving sales success may not, of itself, enable a salesperson to avoid failure. While an individual's performance may be good enough to make sales, their achievement, relative to their peers, may be such that management deem them to have failed in their role (Johnson, Friend, Rutherford, et al., 2016). Additionally, it would appear that much of the extant literature focuses on a single buyer-seller interaction, with a binary outcome of success or failure (Fine, 2007; Friend et al., 2014; Johnson, Friend, Rutherford, et al., 2016; Mallin \& Mayo, 2006; Morris et al., 1994). Sales relationships, however, may take a long time to develop and include many interactions, suggesting that selling may be a process within which no one single event determines success or failure (Davies \& Ryals, 2014). Furthermore, while making a sale may appear to be success from the perspective of the salesperson, selling to a customer who does not have the right long-term fit for the organisation may constitute a failure of sales management or strategy (Davies \& Ryals, 2014; Heidenreich, Wittkowski, Handrich, \& Falk, 2014). All of this leads to the suggestion that achieving sales performance of itself is not sufficient to avoid overall sales failure (Davies \& Ryals, 2014; Heidenreich et al., 2014; Johnson, Friend, Rutherford, et al., 2016). Furthermore, it offers an insight to the relationships between sales strategy, sales management and selling effort and recommends consideration of how each contribute to the ability of the selling organisation to achieve its full potential.

While there appears to be extant literature in respect of antecedents of sales failure relating to individual constructs, for example, sales strategy (Friend et al., 2014), the ability and performance of salespeople (Morris et al., 1994), or the management of the salesforce (Plank et al., 2018) it would appear the fuller context in which all elements that simultaneously and 
explicitly impact sales failure have yet to be considered. Thus, it would appear that the lack of literature in respect of antecedents and detrimental effects of overall sales failure, has yet to be fully investigated. As such there is the need for a review article. Review articles help to bring clarity and order to extant literature and aid researchers by identifying potential avenues for future research (Khusainova et al., 2018). Considering the pace of change currently affecting sales and sales management practice (Khusainova et al., 2018), it would appear that a timely review of extant literature pertaining to sales failure would provide clarity in relation to both individual and interrelated constructs. Accordingly, this paper seeks to synthesise findings from literature in respect of the performance and failure of sales strategy, salespeople and sales management, reporting on the antecedents of sales failure and provide suggestions for new areas of research.

This article therefore proceeds with a description of the methods and quality assurance procedures used during the systematic review. Findings are then presented and discussed, followed by conclusions and recommendations for future research.

\section{Methodology}

In undertaking the review presented here, a structured, transparent, reproducible, evidencebased approach was taken to selecting and assessing contributions (Tranfield, Denyer, \& Smart, 2003). Moreover, a funnelling approach was taken to collecting the data and refining it to achieve clarity and focus (Khusainova et al., 2018).

So as to garner expert opinion on the topic, delegates at one academic and one practitioner conference were also consulted. In June 2017, 17 practitioner delegates took part in a 1-day workshop at the Sales Performance Association (SPA) annual conference. The SPA was selected as delegates are professional sales trainers, who could reasonably be expected to have relevant experience. In May 2018 leading sales academics were consulted at the Sales 
Educators Academy conference. The author would like to thank the delegates of both conferences for their valuable input into this paper.

Publish or Perish, an automated software tool, was used to conduct a wide range of initial searches (Harzing, 2013; Harzing \& Alakangas, 2016; Martin-Martin, Orduna-Malea, Harzing, \& Delgado López-Cózar, 2017). The date range employed was 1980-2018. Search terms included adaptive selling, buyer-seller relationships, buying centre, challenger sale, consultative selling, co-creation of value, customer relationship management, customerorientated selling, customer service failure, ethical sales, key account management (KAM), new business development, relationship marketing, sales failure, sales management, sales strategy, sales technology, service dominant logic, social exchange, spin selling and synonyms thereof. In all, 5,650 articles were downloaded and inspected. Following the removal of duplicates, articles and reports that had not been published in peer-reviewed academic journals and those written in a language other than English, a total of 1,049 articles were identified as potentially relevant. After further filtering by abstract and conclusions, some 104 articles were identified, upon which this review is based. Please see Table 1 for details of the journals and Figure 1 for distribution by age.

Table 1: Journals

\begin{tabular}{|l|l|}
\hline Journal & $\begin{array}{l}\text { Number of } \\
\text { articles }\end{array}$ \\
\hline Industrial Marketing Management & 23 \\
\hline Journal of Personal Selling \& Sales Management & 19 \\
\hline Journal of Business and Industrial Marketing & 9 \\
\hline Journal of Theory and Practice & 8 \\
\hline Journal of Marketing & 6 \\
\hline Journal of the Academy of Marketing Science & 5 \\
\hline Journal of Organizational Effectiveness: People and Performance & 3 \\
\hline European Management Journal & 2 \\
\hline European Journal of Marketing & 2 \\
\hline Journal of Business Research & 2 \\
\hline Journal of Marketing Research & 2 \\
\hline
\end{tabular}




\begin{tabular}{|l|l|}
\hline Academy of Management Review & 1 \\
\hline Business Horizons & 1 \\
\hline Computers in Industry & 1 \\
\hline International Journal of Ergonomics & 1 \\
\hline International Journal of Marketing Studies & 1 \\
\hline International Journal of Research in Marketing & 1 \\
\hline International Journal of Retail \& Distribution Management & 1 \\
\hline International Journal of Selection \& Assessment & 1 \\
\hline Journal of Applied Psychology & 1 \\
\hline Journal of Business Ethics & 1 \\
\hline Journal of Economics, Finance \& Administrative Science & 1 \\
\hline Journal of Marketing Education & 1 \\
\hline Journal of Operations Management & 1 \\
\hline Journal of Purchasing and Supply Management & 1 \\
\hline Journal of Relationship Marketing & 1 \\
\hline Journal of Retailing and Consumer Services & 1 \\
\hline Journal of Services Research & 1 \\
\hline Journal of Transnational Management & 1 \\
\hline Management Revue & 1 \\
\hline Marketing Intelligence and Planning & 1 \\
\hline Personnel Review & 1 \\
\hline Psychology \& Marketing & 1 \\
\hline Risk Management & 1 \\
\hline
\end{tabular}

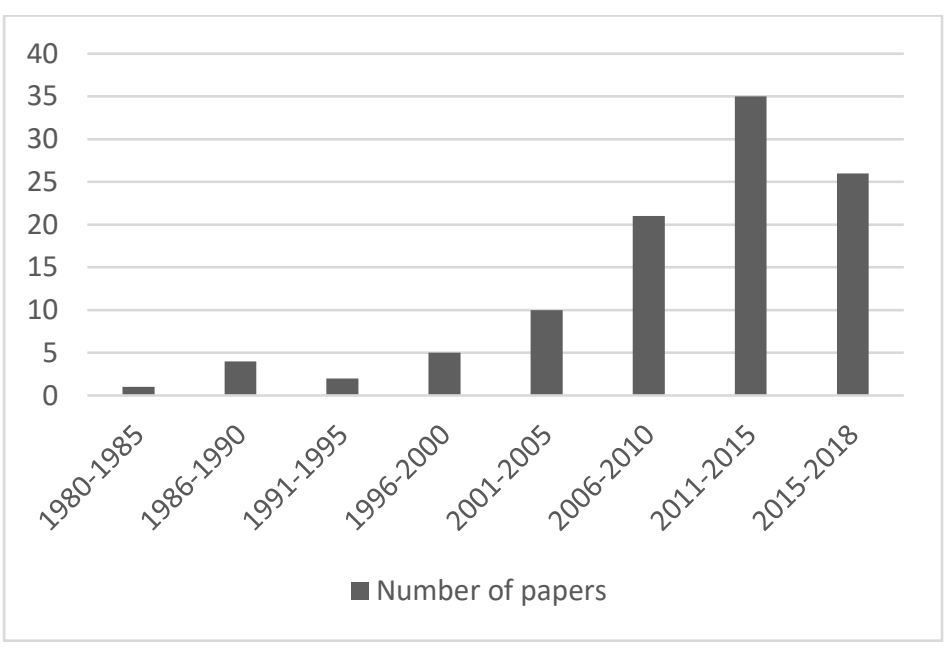

Figure 1: Distribution of papers by age of publication

The investigation into literature pertaining to sales failure identified 104 papers of interest.

The conclusions of these papers were then thematically coded through the application of the

Braun and Clarke (2006) six-stage process, as shown in Table 2. An initial 384 researcher- 
derived codes were created. Said nodes were developed into 54, which during phases 4,5 and

6 became main themes comprising sales strategy, salespeople and sales management.

Within these 3 themes, 8 sub-themes were identified, comprising 36 topics. A discussion of each theme, sub-theme and topic is presented in this section, arranged as shown in Table 3.

Table 2: Data analysis process adapted from Braun \& Clarke (2006)

\begin{tabular}{|l|l|l|}
\hline Phase & Description & Action \\
\hline 1 & $\begin{array}{l}\text { Data } \\
\text { familiarisation }\end{array}$ & $\begin{array}{l}\text { 104 articles were read and re-read to achieve immersion } \\
\text { in the data. }\end{array}$ \\
\hline 2 & $\begin{array}{l}\text { Generating initial } \\
\text { codes }\end{array}$ & $\begin{array}{l}\text { The whole data corpus was reviewed. 384 researcher- } \\
\text { derived initial codes were developed. Code descriptions } \\
\text { were developed to ensure consistency of coding. All } \\
\text { codes were checked and re-checked 4 times to ensure } \\
\text { validity of the data contained within. }\end{array}$ \\
\hline 3 & $\begin{array}{l}\text { Searching for } \\
\text { themes }\end{array}$ & $\begin{array}{l}\text { The data corpus was reviewed, New initial codes were } \\
\text { introduced, and existing codes merged as new potential } \\
\text { themes emerged from the data. After 4 reviews of the } \\
\text { data, 54 potential themes were identified. }\end{array}$ \\
\hline 4 & $\begin{array}{l}\text { Reviewing } \\
\text { themes }\end{array}$ & $\begin{array}{l}\text { Theme descriptions were developed to ensure } \\
\text { consistency. After 4 reviews of the data, 10 themes } \\
\text { emerged. Each had sub themes. }\end{array}$ \\
\hline 5 & $\begin{array}{l}\text { Defining and } \\
\text { naming themes }\end{array}$ & $\begin{array}{l}\text { Further analysis to refine themes and ensure clarity and } \\
\text { consistency was conducted. After 4 reviews of the data, } \\
\text { the final themes of failure of sales strategy, failure of } \\
\text { salesperson and failure of sales management were } \\
\text { developed. Sub themes and topics were named and } \\
\text { checked for consistency. }\end{array}$ \\
\hline 6 & $\begin{array}{l}\text { Producing the } \\
\text { report }\end{array}$ & $\begin{array}{l}\text { Analysis continued throughout the writing-up of the } \\
\text { article and during the revision process. A recursive } \\
\text { approach was taken to allow for additional codes and } \\
\text { themes to be created and included in analysis up to } \\
\text { completion of the project. This resulted in name changes } \\
\text { for 2 topics, so as to ensure clarity and consistency. }\end{array}$ \\
\hline
\end{tabular}

Table 3: Themes and sub-themes

\begin{tabular}{|l|l|l|l|}
\hline Theme & Sub-theme & Topic & Case examples \\
\hline $\begin{array}{l}\text { Failure of sales } \\
\text { strategy }\end{array}$ & Segmentation & Presence of & Cron, Baldauf, Leigh, \& \\
& & & $\begin{array}{l}\text { Grossenbacher, 2014; } \\
\text { Panagopoulos \& } \\
\text { Avlonitis, 2010; Terho, }\end{array}$ \\
\hline
\end{tabular}




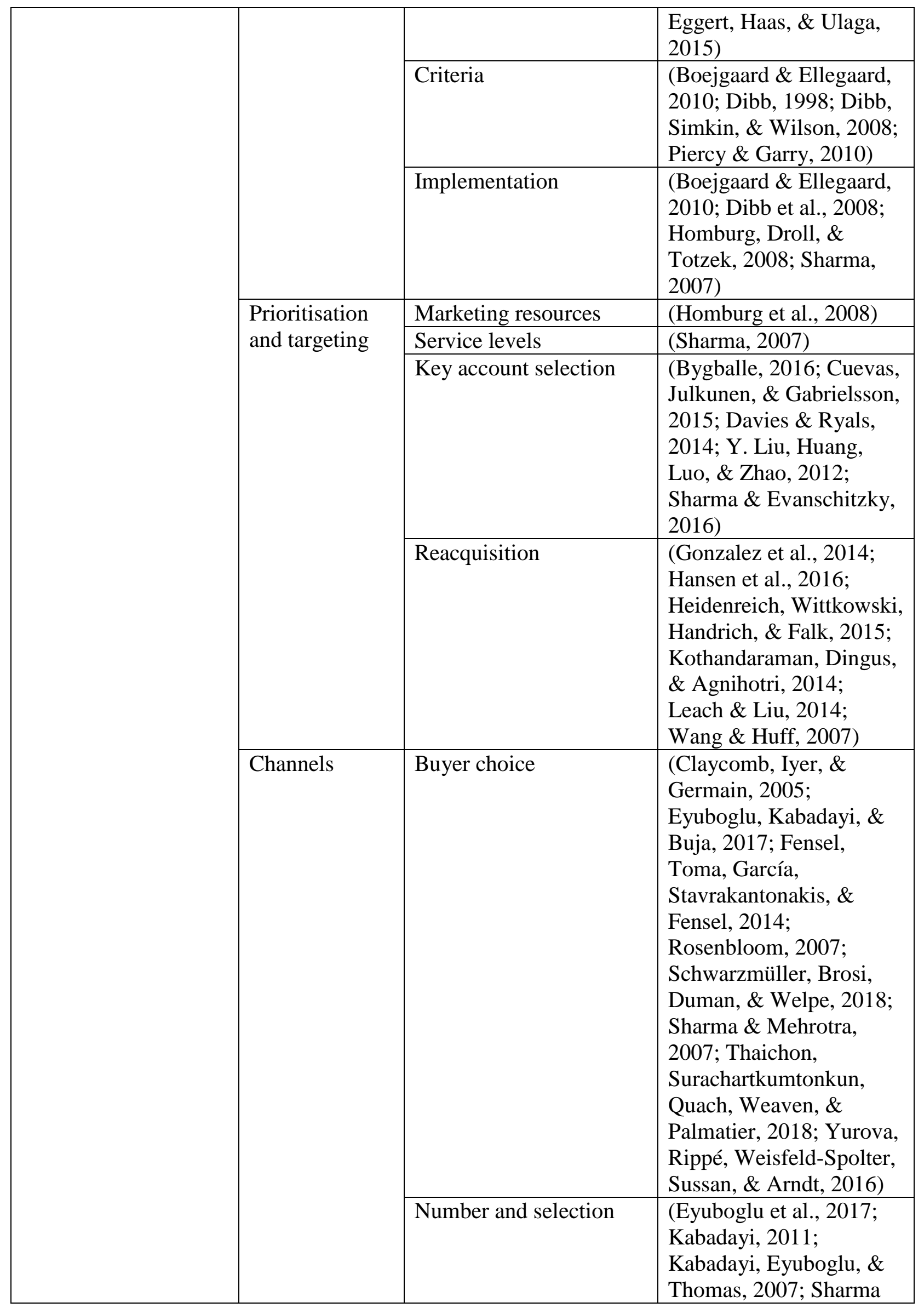




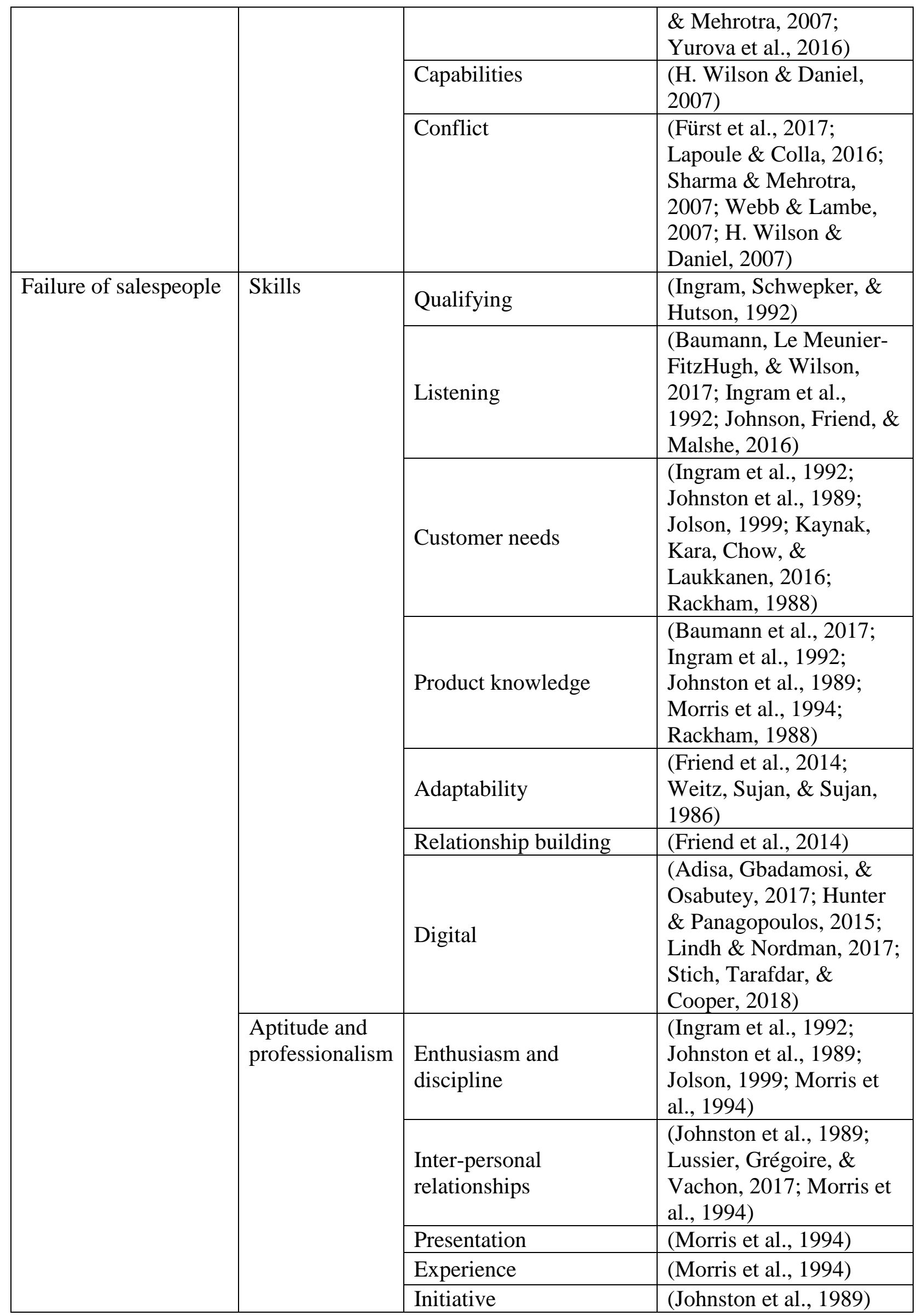




\begin{tabular}{|c|c|c|c|}
\hline & & $\begin{array}{l}\text { Organisation and } \\
\text { administration }\end{array}$ & $\begin{array}{l}\text { (Johnston et al., 1989; } \\
\text { Morris et al., 1994) }\end{array}$ \\
\hline & & Ethics & $\begin{array}{l}\text { (Bolander, Zahn, Loe, \& } \\
\text { Clark, 2015; Guenzi, De } \\
\text { Luca, \& Spiro, 2016; } \\
\text { Wang \& Huff, 2007) }\end{array}$ \\
\hline & \multirow[t]{5}{*}{$\begin{array}{l}\text { Psychological } \\
\text { factors }\end{array}$} & Motivation & $\begin{array}{l}\text { (Khusainova et al., 2018; } \\
\text { Mallin, Gammoh, } \\
\text { Pullins, \& Johnson, } \\
\text { 2017). }\end{array}$ \\
\hline & & PsyCap & $\begin{array}{l}\text { (Friend, Johnson, } \\
\text { Luthans, \& Sohi, 2016) }\end{array}$ \\
\hline & & Personality & $\begin{array}{l}\text { (Ingram et al., 1992; } \\
\text { David A. Locander, } \\
\text { Mulki, \& Weinberg, } \\
\text { 2014; D. A. Locander, } \\
\text { Weinberg, Mulki, \& } \\
\text { Locander, 2015; Lussier } \\
\text { et al., 2017; Major, } \\
\text { Turner, \& Fletcher, 2006; } \\
\text { Mulki, Jaramillo, \& } \\
\text { Locander, 2006; Mulki, } \\
\text { Locander, Marshall, } \\
\text { Harris, \& Hensel, 2008; } \\
\text { K. Wilson \& Woodburn, } \\
\text { 2014) }\end{array}$ \\
\hline & & Orientation & $\begin{array}{l}\text { (Guenzi, 2003; Guenzi et } \\
\text { al., 2016; Saxe \& Weitz, } \\
\text { 1982; Terho et al., 2015) }\end{array}$ \\
\hline & & Coping with failure & $\begin{array}{l}\text { (Badovick, 1990; } \\
\text { DeCarlo, Agarwal, \& } \\
\text { Vyas, 2007; Dixon \& } \\
\text { Schertzer, 2005; Andrea } \\
\text { L. Dixon et al., 2003; A. } \\
\text { L. Dixon, Spiro, \& Jamil, } \\
\text { 2001; Gonzalez et al., } \\
\text { 2005; Goodwin et al., } \\
\text { 1997; Harmon, Brown, } \\
\text { Widing, \& Hammond, } \\
\text { 2002; Johnson, Friend, } \\
\text { Rutherford, et al., 2016; } \\
\text { Mallin \& Mayo, 2006; } \\
\text { Mayo \& Mallin, 2010; } \\
\text { Steward, Hutt, Walker, \& } \\
\text { Kumar, 2009; Teas \& } \\
\text { McElroy, 1986) }\end{array}$ \\
\hline $\begin{array}{l}\text { Failure of sales } \\
\text { management }\end{array}$ & Attributes & Skills & $\begin{array}{l}\text { (Powers, DeCarlo, \& } \\
\text { Gupte, 2010; Powers, } \\
\text { Jennings, \& DeCarlo, } \\
\text { 2014) }\end{array}$ \\
\hline
\end{tabular}




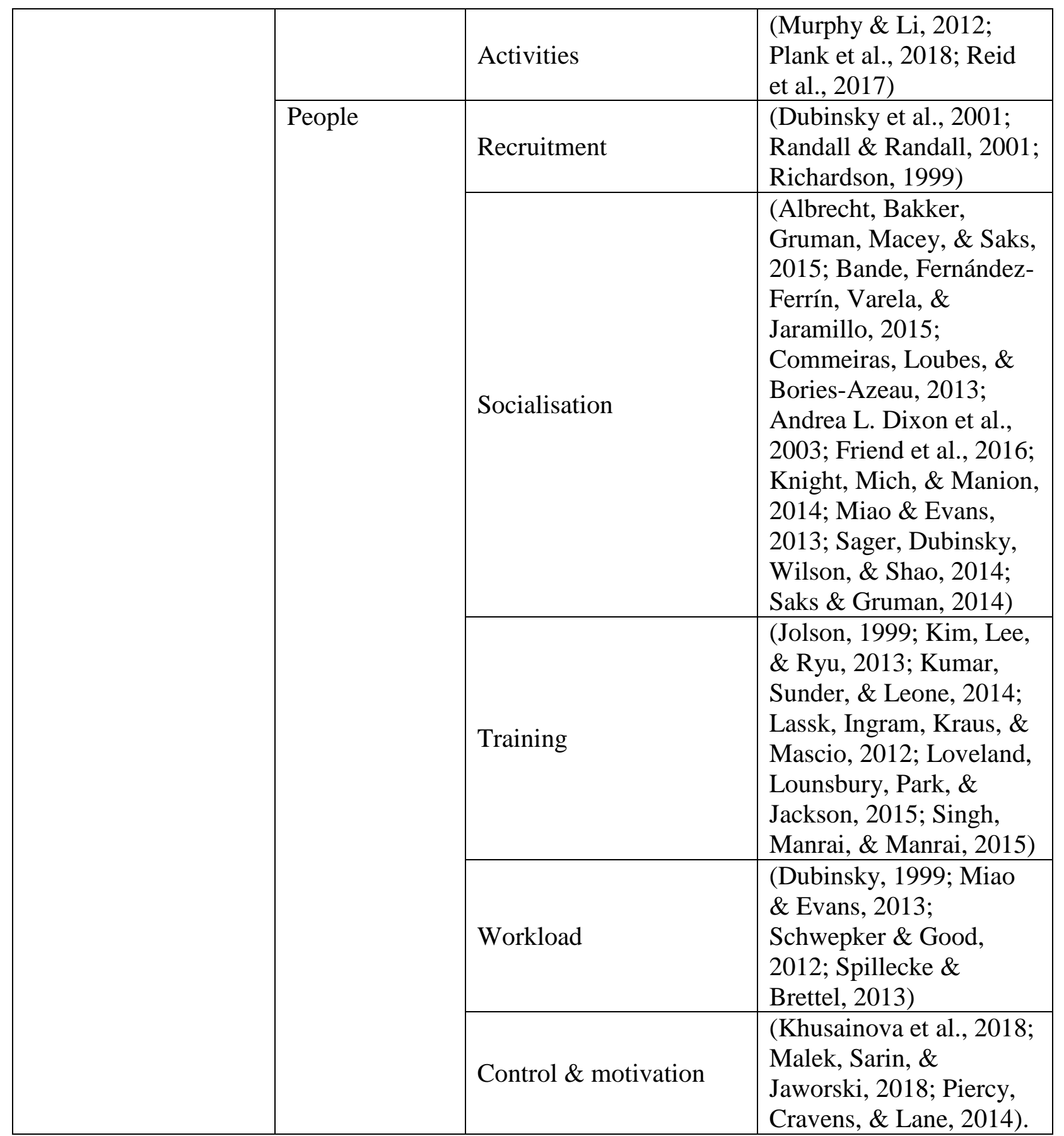

\section{Descriptive results}

Thematic analysis of 104 papers of interest suggested 3 main themes, 8 sub-themes and 36 topics, in relation sales failure. Findings suggest a synergistic relationship between the selling strategy of the firm, management capability to enact strategy through their teams as well as the skills, aptitude, professionalism and psychological factors associated with salespeople, without all of which, an organisation is unlikely to meet its full sales potential. According, 
this section is structured as follows, firstly, it presents a discussion about each theme and sub theme (as presented in Table 3), secondly, a new construct called overall sales failure is proposed, and a measurement framework is presented.

\subsection{Failure of sales strategy}

Selling strategy enables a firm to organise how it selects and engages with customers (Cron et al., 2014). Both academics and practitioners alike deem strategy an area still requiring attention, there being a relative dearth of extant literature based upon empirical findings. Topics that emerged from the data in relation to strategy are segmentation, prioritisation and targeting and, channels. This section considers these constructs in order to determine how and why sales failure may occur.

\subsubsection{Segmentation}

Literature relating to the failure of selling segmentation is sub-divided into the topics of presence (or lack of), criteria used to segment, and implementation of segmentation, as shown in Table 4. It would appear axiomatic that the lack of a clearly defined and articulated segmentation strategy could lead to sales failure, as without appropriate segmentation, scarce resources cannot be targeted in the most effective manor (Panagopoulos \& Avlonitis, 2010). Furthermore, evidence suggests that segmentation is required to enable salespeople to identify and develop the appropriate selling behaviours since, without a clear target, it is more difficult to meet the needs of the particular customer to whom they are selling (Terho et al., 2015).

Table 4: Failure of sales strategy: Segmentation

\begin{tabular}{|l|l|l|}
\hline Key point & Overview of theory & Relevant papers \\
\hline \multirow{3}{*}{ Presence of } & $\begin{array}{l}\text { Lack of sales strategy impacts performance. } \\
\text { Missing segmentation, prioritisation and } \\
\text { targeting, relationship objectives and selling } \\
\text { models and use of sales channels may negatively } \\
\text { impact performance. }\end{array}$ & $\begin{array}{l}\text { (Cron et al., 2014; } \\
\text { Panagopoulos \& } \\
\text { Avlonitis, 2010; } \\
\text { Terho et al., 2015) }\end{array}$ \\
\hline
\end{tabular}




\begin{tabular}{|l|l|l|}
\hline \multirow{5}{*}{ Criteria } & $\begin{array}{l}\text { Traditional criteria (revenue, size, industry and } \\
\text { location) may lack the depth of insight needed to } \\
\text { fully understand a customer and thereby } \\
\text { understand their suitability to be served. Such } \\
\text { criteria may not provide clarity over } \\
\text { homogeneous needs and buying behaviour. }\end{array}$ & $\begin{array}{l}\text { (Boejgaard \& } \\
\text { Ellegaard, 2010; } \\
\text { Dibb, 1998; Dibb } \\
\text { et al., 2008; Piercy } \\
\text { \& Garry, 2010) }\end{array}$ \\
\hline \multirow{5}{*}{ Implementation } & $\begin{array}{l}\text { Barriers to segmentation include infrastructure, } \\
\text { organisation, process, staff motivation, } \\
\text { adaptation and customisation. }\end{array}$ & $\begin{array}{l}\text { (Boejgaard \& } \\
\text { Ellegaard, 2010; } \\
\text { Dibb et al., 2008; } \\
\text { Homburg et al., } \\
\text { 2008; Sharma, } \\
\text { 2007) }\end{array}$ \\
\hline
\end{tabular}

For those who segment, the use of both quantitative and qualitative measures for market attractiveness and business strengths is recommended (Dibb, 1998). Traditional measures of revenue, size, industry and location may not offer the depth of insight needed, as such criteria may not provide the clarity over homogeneous needs and buying behaviour needed to enable comprehensive and in-depth segmentation to occur (Dibb, 1998).

Barriers to the implementation of a segmentation strategy may include lack of appropriate infrastructure, including systems that deliver suitable data. Furthermore, organisational capability including suitability of qualified staff with time available for planning; process design capability or resources may also influence implementation. Additionally, the capability to customise the product/service to meet segment needs, internal marketing to promote sales force motivation and equipping the sales team with the skills and authority to adapt the offer all determine the ability of the organisation to adopt effectively a segmentation strategy. (Boejgaard \& Ellegaard, 2010; Dibb et al., 2008; Piercy \& Garry, 2010). Once segmented, customer segments need to be prioritised and appropriate resources applied (Homburg et al., 2008).

Debate in the literature relates to the efficacy of segmentation, prioritisation and targeting, when considered at the level of implementation (or not). Whilst scholars broadly agree that segmentation should take place, disagreement appears to pertain to the relative profitability of 
various customer segments (Homburg et al., 2008; Sharma, 2007). Sharma (2007) promotes focusing limited selling effort on a large number of transactional customers, as this enables the level of service to be tailored to the minimum required to promote purchase and repurchase, thus reducing costs and maximising revenue. It is noted that, while this approach offers the most revenue, it comes at the cost of customer loyalty (Sharma, 2007). Homburg et al. (2008) promote directing higher levels of customer-orientated selling techniques towards a smaller number of longer-term relationships with larger customers. They claim this approach generates greater profit over the long term. This is achieved through better customer satisfaction and increased loyalty, making it possible to acquire a larger share of the customers' wallet, while at the same time reducing marketing and sales costs (Homburg et al., 2008). This suggests that, in order to maximise profit, a firm must recognise the needs of each segment and staff and support accordingly.

\subsubsection{Prioritisation and targeting}

While segmentation is a useful strategy, it does not stand-alone. The purpose of segmentation is to enable appropriate prioritisation and targeting of the customer. Table 5 identifies the topics associated with prioritisation and targeting. As previously mentioned, applying more sales resources to larger and potentially more profitable customers may lead to greater longterm profit (Homburg et al., 2008). Yet, other customer segments may also offer profitable business (Sharma, 2007). Targeting resources at differing customer segments enables expenditure to be controlled to that appropriate to each. Failure to do so by, e.g. overresourcing transactional customers or under-resourcing key accounts, may lead to unnecessary expenditure, or sales failure due to the mismatch between seller and buyer expectations. 
Table 5: Failure of sales strategy: Prioritisation and targeting

\begin{tabular}{|l|l|l|}
\hline Key point & Overview of theory & Relevant papers \\
\hline $\begin{array}{l}\text { Marketing } \\
\text { resources }\end{array}$ & $\begin{array}{l}\text { Failing to prioritise customers may lead to } \\
\text { inefficient and ineffective use of sales resources. }\end{array}$ & $\begin{array}{l}\text { (Homburg et al., } \\
\text { 2008) }\end{array}$ \\
\hline $\begin{array}{l}\text { Service } \\
\text { levels }\end{array}$ & $\begin{array}{l}\text { Prioritisation may positively affect customer } \\
\text { retention by providing a means of serving customers } \\
\text { with precisely the level of service needed secure the } \\
\text { business. It may also lower costs by reducing the } \\
\text { levels of service to match customer lifetime value. }\end{array}$ & (Sharma, 2007) \\
\hline $\begin{array}{l}\text { Key account } \\
\text { selection }\end{array}$ & $\begin{array}{l}\text { Even when the right accounts are selected, it can } \\
\text { take a considerable amount of time to recoup } \\
\text { investment in KAM. Selection of the wrong } \\
\text { accounts may result in inappropriate prioritisation } \\
\text { and wastage of limited resources. Care must be } \\
\text { taken to avoid customers who may choose to use } \\
\text { buyer-power to demand lower prices. }\end{array}$ & $\begin{array}{l}\text { (Bygballe, 2016; } \\
\text { Cuevas et al., 2015; } \\
\text { Davies \& Ryals, } \\
\text { 2014; Y. Liu et al., } \\
\text { 2012; Sharma \& } \\
\text { Evanschitzky, 2016) }\end{array}$ \\
\hline Reacquisition & $\begin{array}{l}\text { Targeting lost customers may result in future repeat } \\
\text { business. Action to recover from service failure may } \\
\text { minimise loss or facilitate reacquisition. Customers } \\
\text { who co-create a solution may be more invested in } \\
\text { the relationship, and therefore loss is more } \\
\text { significant with greater negative consequences, and } \\
\text { subsequent reacquisition is more difficult. }\end{array}$ & $\begin{array}{l}\text { (Gonzalez et al., } \\
\text { 2014; Hansen et al., } \\
\text { 2016; Heidenreich et } \\
\text { al., 2015; } \\
\text { Kothandaraman et } \\
\text { al., 2014; Leach \& } \\
\text { Liu, 2014; Wang \& } \\
\text { Huff, 2007) }\end{array}$ \\
\hline
\end{tabular}

Much has been written about developing longer-term relationships with larger customers, under the banner of Key Account Management (KAM). KAM posits that selling firms will organise resources and people to build a deep and long-term relationship with customers that enables co-creation of value for both parties (Davies \& Ryals, 2014). To be successful, KAM relationships depend upon both significant investment by the seller and commitment from the buyer (Davies \& Ryals, 2014). Both parties need to agree objectives that deliver mutual business benefit. Not selecting key accounts judiciously or failing to monitor the quality, value and cost of the relationship can lead to sales failure (Davies \& Ryals, 2014; Sharma \& Evanschitzky, 2016). 
KAM relationships take time to develop and become profitable. Relationships may take longer and cost more to service than expected (Cuevas et al., 2015; Davies \& Ryals, 2014). Therefore, failure by the seller to provide adequate resources and preparedness for the significant time lag between investment and return, may lead to failure (Davies \& Ryals, 2014). Additionally, changes in personnel or, more significantly, strategy changes over time by either buying or selling firms may have the potential to cause KAM failure (Bygballe, 2016; Sharma \& Evanschitzky, 2016). Furthermore, due to power imbalances between sellers and customers, some KAM buyers may feel able to unfairly demand lower prices (Cuevas et al., 2015; Y. Liu et al., 2012). Not only can lower prices negatively affect profitability, but attempting to hold out for higher prices may be perceived by buyers as not dealing fairly (Johnson, Friend, \& Malshe, 2016). All this suggests that while correctly selecting KAM accounts has the potential to increase sales incorrect selection may lead to poor resource allocation, additional costs and potential for sales failure, resulting in loss of the investment in time and resources to win and nurture the account, and also the loss of potential future revenue.

Indeed, this suggests that, upon failure, a reacquisition strategy should be considered (Gonzalez et al., 2014). Reacquisition failure is primarily caused by not having a strategy to target and prioritise lost customers. Yet, when carried out effectively, reacquisition may provide a competitive advantage (Gonzalez et al., 2014). When service failure occurs, trust between buyer and seller may be diminished (Hansen et al., 2016; Wang \& Huff, 2007). Buyer perception of the salesperson's propensity towards selling orientation (SO), which is where a salesperson values closing an order, or customer-orientation $(\mathrm{CO})$, which is where a salesperson values the customer relationship, is important, as such perception may determine the nature of rectification required by the customer (Hansen et al., 2016). If a buyer believes the salesperson deliberately provided misleading information, acted unethically or 
opportunistically to close the order (SO behaviour), then trust will be more significantly diminished, and the buyer may require financial compensation. Yet, if the buyer believes the salesperson was acting in their best interests and the service failure was an honest mistake (CO behaviour), trust may be increased through the actions of the salesperson to rectify the situation. Additionally, the buyer may also prefer an apology, failure to provide one potentially promoting negative reactions (Hansen et al., 2016).

To be successful at reacquisition, salespeople should also be provided with enough time to identify lost customers and be rewarded for reacquisition (Gonzalez et al., 2014;

Kothandaraman et al., 2014; Leach \& Liu, 2014). Salespeople need to identify the reason for loss and determine the value of the customer and the effort required, so as to ensure that reacquisition is profitable (Leach \& Liu, 2014). Additionally, it is claimed that the level of customer involvement with the co-creation of value is an important factor in customer reacquisition, as the more significant the customer investment, the more difficult it will be to reacquire said customers (Heidenreich et al., 2015). Yet, interestingly, if handled correctly, service recovery can promote long-term profitable buyer-seller relationships (Gonzalez et al., 2005; Widmier \& Jackson Jr, 2002).

\subsubsection{Channels}

Sales channels is the third area of sales strategy identified. Nowadays, there are a plethora of sales channels, through which buyers can choose to interact with sellers (Eyuboglu et al., 2017; Fensel et al., 2014; Rosenbloom, 2007). This suggests that buyer choice, number, selection and capabilities of channels (as shown in Table 6) are areas worthy of further investigation.

Table 6: Failure of sales strategy: Channels

\begin{tabular}{|l|l|l|}
\hline Key point & Overview of theory & Relevant papers \\
\hline
\end{tabular}




\begin{tabular}{|c|c|c|}
\hline $\begin{array}{l}\text { Buyer } \\
\text { choice }\end{array}$ & $\begin{array}{l}\text { Customers are demanding and sellers are } \\
\text { able to offer more channel options. Choice } \\
\text { may increase costs as more channels may } \\
\text { not lead to more business. Customers may } \\
\text { select which channel to use depending } \\
\text { upon their current needs. Use of multiple } \\
\text { channels suggests that it is important to } \\
\text { ensure that the customer receives the same } \\
\text { offer across all of the channels that are } \\
\text { available to them. }\end{array}$ & $\begin{array}{l}\text { (Claycomb et al., 2005; } \\
\text { Eyuboglu et al., 2017; } \\
\text { Fensel et al., 2014; } \\
\text { Rosenbloom, 2007; } \\
\text { Schwarzmüller et al., 2018; } \\
\text { Sharma \& Mehrotra, 2007; } \\
\text { Thaichon et al., 2018; } \\
\text { Yurova et al., 2016) }\end{array}$ \\
\hline $\begin{array}{l}\text { Number and } \\
\text { selection }\end{array}$ & $\begin{array}{l}\text { It is important to consider the prospect of } \\
\text { channel cannibalisation, not reaching } \\
\text { intended customer segments, and poor } \\
\text { integration resulting in customer } \\
\text { dissatisfaction. Indeed, when taking this } \\
\text { into account it seems that it is not just the } \\
\text { number of channels but the channel mix } \\
\text { and how well the mix is coordinated and } \\
\text { integrated that determine how the customer } \\
\text { base is affected by multi-channel strategy. } \\
\text { Furthermore, not all channels are suitable } \\
\text { for all types of customers or products. }\end{array}$ & $\begin{array}{l}\text { (Eyuboglu et al., 2017; } \\
\text { Kabadayi, 2011; Kabadayi } \\
\text { et al., 2007; Sharma \& } \\
\text { Mehrotra, 2007; Yurova et } \\
\text { al., 2016) }\end{array}$ \\
\hline Capabilities & $\begin{array}{l}\text { Without management attention at the } \\
\text { tactical level, highly coordinated and } \\
\text { integrated channel campaigns are not } \\
\text { achievable. Dynamic capabilities provide } \\
\text { competitive advantage in a multi-channel } \\
\text { environment, with said capabilities } \\
\text { including the alignment of route to market } \\
\text { with segment and product characteristics, } \\
\text { integration of processes and IT to support } \\
\text { channels, and metrics and rewards which } \\
\text { are reflective of customer behaviours. }\end{array}$ & (H. Wilson \& Daniel, 2007) \\
\hline Conflict & $\begin{array}{l}\text { Unclear goals for channels, ineffective } \\
\text { internal communication and internal } \\
\text { coordination can all bring rise to conflicts } \\
\text { which disrupt the performance of } \\
\text { multichannel sales. Without the } \\
\text { distribution of tasks in a manner that } \\
\text { enhances cooperation among channel } \\
\text { members (direct sales forces, resellers, } \\
\text { etc.), multichannel strategies may foster } \\
\text { fear of competition or exclusion which } \\
\text { may lead to sales failure. }\end{array}$ & $\begin{array}{l}\text { (Fürst et al., 2017; Lapoule } \\
\text { \& Colla, 2016; Sharma \& } \\
\text { Mehrotra, 2007; Webb \& } \\
\text { Lambe, 2007; H. Wilson \& } \\
\text { Daniel, 2007) }\end{array}$ \\
\hline
\end{tabular}

Offering multiple channels appears to suggest improvements in reach and service capability,

which overall should lead to greater customer satisfaction and a propensity to repurchase 
(Sharma \& Mehrotra, 2007). Yet, there is some suggestion that more channels may not necessarily lead to more sales, there being debate in relation to the benefit of additional sales channels for the supplier (Sharma \& Mehrotra, 2007).

While suppliers may determine a channel strategy, it is ultimately the buyer who determines use (H. Wilson \& Daniel, 2007). Increasing the number of channels available to buyers may increase sales (Kabadayi et al., 2007). While it may be that customers demand more channels, the impact on the organisation may be an increase in costs, resource requirements, complexity, competitive pressure and reduced overall profitability (Sharma \& Mehrotra, 2007; H. Wilson \& Daniel, 2007). Furthermore, maintaining consistency of offer and seamless handover between channels may require additional technology, which may also increase operating costs (Sharma \& Mehrotra, 2007; H. Wilson \& Daniel, 2007). Advice pertaining how to maximise profitability appears to be limited. However, Sharma and Mehrotra (2007) posit that coverage, profitability, optimal mix, rules to avoid conflict and critical channels should be evaluated to produce a strategy. Moreover, Kabadayi (2011) suggests that, to be successful, the channels offered need to support overall firm strategy, the nature of the trading environment and product being the determining factors. Eyuboglu et al. (2017) extend this concept and posit that the level of uncertainty in the target segment is the factor determining complexity of channel structure.

As previously mentioned, managing a more complex channel arrangement requires sales leaders to determine the channel combinations most appropriate for each customer segment (H. Wilson \& Daniel, 2007). "Dynamic capabilities” (H. Wilson \& Daniel, 2007, p. 10) are required to provide competitive advantage and avoid conflict in a multichannel environment; said capabilities include the alignment of route to market with segment and product characteristics, integration of processes and IT to support channels, and metrics and rewards which are reflective of customer behaviours (H. Wilson \& Daniel, 2007). 
Failure to implement a management structure that supports and rewards cooperation between channels may lead to conflict and cannibalism (Fürst et al., 2017; Webb \& Lambe, 2007; H. Wilson \& Daniel, 2007). Conflict can be avoided by creating differentiation between the tasks offered by each channel and by ensuring that each is designed to attract and service a specific customer segment (Fürst et al., 2017). Reducing the desire of one channel to cannibalise another reduces waste, reduces cost and increases profitability (Lapoule \& Colla, 2016; Webb \& Lambe, 2007).

This review of literature appears to suggest a lack of sales strategy has the potential to promote sales failure (Cron et al., 2014). Yet, it would also appear that there remains debate surrounding the best way to achieve profitability and identify and address differing segments of the market (Homburg et al., 2008; Sharma, 2007; Sharma \& Evanschitzky, 2016). Furthermore, it would seem that new opportunities may exist and be available through the use of digital channels, which with respect to business-to-business usage appears to be a under researched area (Schwarzmüller et al., 2018; Yurova et al., 2016).

\subsection{Failure of salespeople}

Having a great sales strategy, however, may not of itself minimise sales failure, as it is the salespeople who operate in the boundary between supplier and buyer and are trusted to enact it through their activities. This suggests that the role and capability of the salespeople deserve attention next, as it is their actions (or lack thereof) that may determine sales success or failure (Panagopoulos \& Avlonitis, 2010). Failure might occur as a direct result of the techniques applied, skills, knowledge motivation, or actions of salespeople, or for reasons that are out of their sphere of knowledge or influence (Friend et al., 2014; Mallin \& Mayo, 2006; Mayo \& Mallin, 2010). 


\subsubsection{Skills}

Adaptive Selling (Weitz et al., 1986), SPIN selling (Rackham, 1988) and the Challenger Sale

(M. Dixon \& Adamson, 2011) all offer methods claimed to teach successful selling.

Underpinning these theories are a number of key sales skills required to avoid sales failure.

Adaptive Selling encourages salespeople to understand customer requirements and adapt their sales offer to meet those requirements (Weitz et al., 1986). Failure to identify the customer's situation, problems, the implications thereof, and the value the proposed solution will deliver is a potential cause of sales failure (Kaynak et al., 2016; Rackham, 1988). To minimise the chances of failure, the salesperson may need to adapt the sales offer or relationship to meet the expectations of their customer. To achieve this, the salesperson must become adept at listening and comprehending customer needs, remain responsive, avoid arrogance and be prepared to change to meet the buyer's expectations (Friend et al., 2014). In the aforementioned key accounts, adaptiveness is not only required at the buyer-seller relationship level, but also at the inter-organisational relationship level (Friend et al., 2014). This requires salespeople to develop a social network within their customers and their own firm, to enable them to orchestrate inter-organisational relationship development (Kothandaraman et al., 2014; Widmier \& Jackson Jr, 2002).

SPIN selling posits that a salesperson must identify the situation of the customer, understand their problems, encourage the customer to explore the implications of their problem and then explain the value that their solution provides (Rackham, 1988). The Challenger Sale suggests that relationships may be required but are not sufficient to create success. M. Dixon and Adamson (2011) posit that the salesperson and their organisation need to deliver valuable insights so as to induce the customer to buy. This review of selling techniques appears to suggest that a salesperson needs the same skills (as shown in Table 7) when using Adaptive Selling (Weitz et al., 1986), SPIN selling (Rackham, 1988) or Challenger Sale techniques (M. 
Dixon \& Adamson, 2011). Various elements, both individually and in combination, appear to promote sales failure, namely: not qualifying prospects, a failure to listen to customers, which includes comprehension of all forms of communication between parties and comprehension of the messages and signals provided by the customer (Baumann et al., 2017; Johnson, Friend, \& Malshe, 2016), possessing and applying sufficient product knowledge, incorrectly assessing customer needs (Ingram et al., 1992; Johnston et al., 1989; Jolson, 1999), a failure to adapt a proposal and customer relationship to suit the circumstances, or to effectively identify and deliver the appropriate value to the customer (Baumann et al., 2017; Friend et al., 2014).

Table 7: Failure of salespeople: Skills

\begin{tabular}{|c|c|c|}
\hline Key point & Overview of theory & Relevant papers \\
\hline Qualifying & $\begin{array}{l}\text { Failure to assess and qualify prospects brings } \\
\text { about the potential for salespeople to waste } \\
\text { time and resources on a customer who is } \\
\text { without the wherewithal to purchase or for } \\
\text { whom the product/service is inappropriate. }\end{array}$ & (Ingram et al., 1992) \\
\hline Listening & $\begin{array}{l}\text { Poor listening skills was considered to be the } \\
\text { most significant contributor to salesperson } \\
\text { failure. The concept of listening is broader than } \\
\text { what may be heard in a conversation. It applies } \\
\text { to all forms of customer communication, e.g. } \\
\text { in relation to needs, as well as offer and value } \\
\text { potential. }\end{array}$ & $\begin{array}{l}\text { (Baumann et al., 2017; } \\
\text { Ingram et al., 1992; } \\
\text { Johnson, Friend, \& } \\
\text { Malshe, 2016) }\end{array}$ \\
\hline $\begin{array}{l}\text { Customer } \\
\text { needs }\end{array}$ & $\begin{array}{l}\text { An inability to determine customer needs and a } \\
\text { lack of customer orientation were both } \\
\text { considered attributable to sales failure. }\end{array}$ & $\begin{array}{l}\text { (Ingram et al., 1992; } \\
\text { Johnston et al., 1989; } \\
\text { Jolson, 1999; Kaynak } \\
\text { et al., 2016; Rackham, } \\
\text { 1988) }\end{array}$ \\
\hline $\begin{array}{l}\text { Product } \\
\text { knowledge }\end{array}$ & $\begin{array}{l}\text { Inadequate product/service knowledge leading } \\
\text { to offering the wrong product to the wrong } \\
\text { customer, or failure to explain value, may } \\
\text { promote sales failure. }\end{array}$ & $\begin{array}{l}\text { (Baumann et al., 2017; } \\
\text { Ingram et al., 1992; } \\
\text { Johnston et al., 1989; } \\
\text { Morris et al., 1994; } \\
\text { Rackham, 1988) }\end{array}$ \\
\hline Adaptability & $\begin{array}{l}\text { The presence of a non-adaptive sales proposal, } \\
\text { which is the result of a lack of adaptive } \\
\text { capabilities and/or a lack of adaptive attitude } \\
\text { on behalf of the salesperson, were attributed by } \\
\text { buyers to causes of sales failure. }\end{array}$ & $\begin{array}{l}\text { (Friend et al., 2014; } \\
\text { Weitz et al., 1986) }\end{array}$ \\
\hline
\end{tabular}




\begin{tabular}{|c|c|c|}
\hline $\begin{array}{l}\text { Relationship } \\
\text { building }\end{array}$ & $\begin{array}{l}\text { The presence of a non-relational sales } \\
\text { proposal, which is the result of inadequate } \\
\text { collaboration and broken trust by way of the } \\
\text { salesperson, were attributed to sales failure by } \\
\text { buyers. }\end{array}$ & (Friend et al., 2014) \\
\hline Digital & $\begin{array}{l}\text { Rapidly changing ICT requires salespeople to } \\
\text { keep their technology skills relevant. } \\
\text { Furthermore, salespeople need to be taught } \\
\text { how to cope with being constantly available, } \\
\text { which leads to interruptions, divided attention } \\
\text { and a need to multitask; salespeople must also } \\
\text { have the ability to cope with the demands of an } \\
\text { always-on connection to their customers, so as } \\
\text { to avoid stress and burn out. }\end{array}$ & $\begin{array}{l}\text { (Adisa et al., 2017; } \\
\text { Hunter \& } \\
\text { Panagopoulos, 2015; } \\
\text { Lindh \& Nordman, } \\
\text { 2017; Stich et al., } \\
\text { 2018) }\end{array}$ \\
\hline
\end{tabular}

The rapid changes in Information and Communication Technology (ICT) require salespeople to be constantly updating their skills (Hunter \& Panagopoulos, 2015; Stich et al., 2018).

While originally posited as a way to increase productivity and revenue, the adoption of ICT is largely seen by customers as a hygiene factor - one that organisations and salespeople alike are required to meet to be credible (Lindh \& Nordman, 2017). Indeed, as ICT has become widely adopted outside of work, salespeople not only need to be taught appropriate commercial use, but also how to handle the challenges of being constantly connected. Constant connectivity may lead to customer expectations of around-the-clock availability, further leading to work interruptions, divided attention and a need for enhanced multitasking skills. This impacts time at work, but also home-life, with the potential for stress and burnout (Adisa et al., 2017; Stich et al., 2018). It would therefore appear logical that, given the impact of ICT, salespeople must develop and keep their skills updated so as to maximise the benefits and reduce the disadvantages of ICT. Additionally, salespeople need to develop the aptitude and professionalism required to ensure that ICT is used appropriately, effectively and ethically, to which attention is next directed. 


\subsubsection{Aptitude and professionalism}

Continuing the theme identified in the sales skills section, and as shown in Table 8, there appear to be basic standards that customers expect and which, if not met, will lead to sales failure. The topics identified in relation to aptitude and professionalism are what could be expected of most business-orientated roles. Indeed, certain elements appear to be prerequisites to avoidance of sales failure, namely: enthusiasm and discipline, including applying sufficient effort to fulfil the job role (Jolson, 1999), having the personality and ability to get on with others in the workplace, appropriate presentation, including dressing and acting within the social norms of the environment, experience required to do the job to the required standard, and the ability to take the initiative (Ingram et al., 1992; Johnston et al., 1989; Morris et al., 1994). Furthermore, possessing a sense of humour helps to build interpersonal relationships between buyers and sellers (Lussier et al., 2017). In addition, however, selling requires organisation and administrative skills to ensure that promises made to customers are enacted (Johnston et al., 1989; Morris et al., 1994).

Table 8: Failure of salespeople: Aptitude and professionalism

\begin{tabular}{|l|l|l|}
\hline Key point & Overview of theory & Relevant papers \\
\hline $\begin{array}{l}\text { Enthusiasm } \\
\text { and discipline }\end{array}$ & $\begin{array}{l}\text { A lack of enthusiasm or the discipline } \\
\text { required to do the job, is a contributor to the } \\
\text { failure of a salesperson. }\end{array}$ & $\begin{array}{l}\text { (Ingram et al., 1992; } \\
\text { Johnston et al., 1989; } \\
\text { Jolson, 1999; Morris et al., } \\
1994)\end{array}$ \\
\hline $\begin{array}{l}\text { Inter-personal } \\
\text { relationships }\end{array}$ & $\begin{array}{l}\text { Being hard to work with/supervise and } \\
\text { having poor people skills, were both found } \\
\text { to be behaviours indicative of failure. A } \\
\text { sense of humour helps to build inter- } \\
\text { personal relationships between buyers and } \\
\text { sellers. }\end{array}$ & $\begin{array}{l}\text { (Johnston et al., 1989; } \\
\text { et al., 1994) }\end{array}$ \\
\hline Presentation & $\begin{array}{l}\text { Inappropriate dress/appearance was } \\
\text { considered a behaviour indicative of failure. }\end{array}$ & (Morris et al., 1994) \\
\hline Experience & $\begin{array}{l}\text { A lack of experience was shown to be an } \\
\text { indicator of failure. }\end{array}$ & (Morris et al., 1994) \\
\hline Initiative & $\begin{array}{l}\text { A lack of initiative was shown to be an } \\
\text { indicator of failure. }\end{array}$ & (Johnston et al., 1989) \\
\hline
\end{tabular}




\begin{tabular}{|l|l|l|}
\hline $\begin{array}{l}\text { Organisation } \\
\text { and } \\
\text { administration }\end{array}$ & $\begin{array}{l}\text { Poor planning, organisation, administration } \\
\text { skills, poor time management and a failure } \\
\text { to concentrate on priorities, were all } \\
\text { indicators of salesperson failure. }\end{array}$ & $\begin{array}{l}\text { (Johnston et al., 1989; } \\
\text { Morris et al., 1994) }\end{array}$ \\
\hline Ethics & $\begin{array}{l}\text { Unethical behaviour was considered } \\
\text { indicative of failure. }\end{array}$ & $\begin{array}{l}\text { (Bolander et al., 2015; } \\
\text { Guenzi et al., 2016; Wang } \\
\text { \& Huff, 2007) }\end{array}$ \\
\hline
\end{tabular}

Failure to act ethically is also singled out for special attention in the literature, as ethical failure by salespeople reflects not only on the individual(s) concerned, but also the organisation as a whole (Bolander et al., 2015). Furthermore, abuse of power and opportunistic behaviour are both considered unethical behaviours, constituting a breach of trust, with the potential to lead to relationship breakdown and sales failure (Guenzi et al., 2016; Wang \& Huff, 2007).

\subsubsection{Psychological factors}

People undertake the role of personal selling. Being human leads to consideration of the role of emotions (DeCarlo et al., 2007; A. L. Dixon et al., 2001; Steward et al., 2009). This suggests that, to fully understand salespeople, a psychological approach may be required (Friend et al., 2016). Topics include intrinsic and extrinsic motivation, PsyCap, personality, selling/customer orientation and attribution of failure (as shown in Table 9).

Table 9: Failure of salespeople: Psychological factors

\begin{tabular}{|l|l|l|}
\hline Key point & Overview of theory & Relevant papers \\
\hline Motivation & $\begin{array}{l}\text { Lack of intrinsic motivation, personal } \\
\text { goals and ambition are considered factors } \\
\text { contributing to the failure of salespeople. }\end{array}$ & $\begin{array}{l}\text { (Khusainova et al., 2018; Mallin } \\
\text { et al., 2017). }\end{array}$ \\
\hline PsyCap & $\begin{array}{l}\text { It is posited that the psychological capital } \\
\text { constructs of self-efficacy, optimism, } \\
\text { hope and resilience are required to avoid } \\
\text { sales failure. }\end{array}$ & (Friend et al., 2016) \\
\hline Personality & $\begin{array}{l}\text { Personality traits, such as proactiveness } \\
\text { and motivation to learn, impact sales } \\
\text { success and too much ego or emotional } \\
\text { immaturity can contribute to sales }\end{array}$ & $\begin{array}{l}\text { (Ingram et al., 1992; David A. } \\
\text { Locander et al., 2014; D. A. } \\
\text { Locander et al., 2015; Lussier et } \\
\text { al., 2017; Major et al., 2006; }\end{array}$ \\
\hline
\end{tabular}




\begin{tabular}{|c|c|c|}
\hline & $\begin{array}{l}\text { failure. It is also posited that other traits, } \\
\text { including decision making processes, } \\
\text { thinking styles, initiative, social } \\
\text { comparison, supervisory trust and ability } \\
\text { to deal with isolation are all as impactful } \\
\text { on sales success or failure. }\end{array}$ & $\begin{array}{l}\text { Mulki et al., 2006; Mulki et al., } \\
\text { 2008; K. Wilson \& Woodburn, } \\
\text { 2014) }\end{array}$ \\
\hline Orientation & $\begin{array}{l}\text { The salespeople's orientation towards } \\
\text { selling (SO) or customers (CO) appears } \\
\text { to impact relationship and sales success. }\end{array}$ & $\begin{array}{l}\text { (Guenzi, 2003; Guenzi et al., } \\
\text { 2016; Saxe \& Weitz, 1982; } \\
\text { Terho et al., 2015) }\end{array}$ \\
\hline $\begin{array}{l}\text { Coping with } \\
\text { failure }\end{array}$ & $\begin{array}{l}\text { Failure is part of any sales role. How } \\
\text { failure is dealt with by the salesperson } \\
\text { impacts motivation and behaviours and } \\
\text { can itself lead to future sales failure. To } \\
\text { enable salespeople to avoid future } \\
\text { failure, the organisation needs to accept } \\
\text { it and welcome the opportunity to learn. }\end{array}$ & $\begin{array}{l}\text { (Badovick, 1990; DeCarlo et al., } \\
\text { 2007; Dixon \& Schertzer, 2005; } \\
\text { Andrea L. Dixon et al., 2003; A. } \\
\text { L. Dixon et al., 2001; Gonzalez } \\
\text { et al., 2005; Goodwin et al., } \\
\text { 1997; Harmon et al., 2002; } \\
\text { Johnson, Friend, Rutherford, et } \\
\text { al., 2016; Mallin \& Mayo, 2006; } \\
\text { Mayo \& Mallin, 2010; Steward } \\
\text { et al., 2009; Teas \& McElroy, } \\
\text { 1986) }\end{array}$ \\
\hline
\end{tabular}

In respect of motivation, there is a substantial body of literature detailing multiple theories.

Below is a brief overview. Readers requiring a fuller explanation are directed to Khusainova et al. (2018) for a more comprehensive review.

Intrinsic Motivation relates to challenge, enjoyment or satisfaction without reward or payment. Extrinsic Motivation (EM) relates to the rewards and compensation given for achievement (Khusainova et al., 2018; Mallin et al., 2017). PsyCap provides a different lens through which to view motivation. It is defined as a "positive psychological state of development that is characterized by: (1) having confidence (self-efficacy) to take on and put in the necessary effort to succeed at challenging tasks, (2) making a positive attribution (optimism) about succeeding now and in the future, (3) persevering toward goals and, when necessary, redirecting paths to goals (hope) in order to succeed, and (4) when beset by problems and adversity, sustaining and bouncing back and even beyond (resilience) to attain success" (Friend et al., 2016, p. 307). Furthermore, personal selling, when considered through 
the lens of the Big Five factors, suggests that proactive personality and motivation to learn may both impact sales success (Major et al., 2006). Additionally, too much ego or a lack of emotional maturity may contribute to sales failure (Ingram et al., 1992; Major et al., 2006; K. Wilson \& Woodburn, 2014). Furthermore, the impact of decision making processes (David A. Locander et al., 2014), thinking styles (Groza, Locander, \& Howlett, 2016), initiative (Jaramillo, Locander, Spector, \& Harris, 2007), resourcefulness (Lussier et al., 2017), social comparison (D. A. Locander et al., 2015) supervisory trust and feelings of positive organisational support (Mulki et al., 2006), and how feelings of isolation are managed, may all impact the performance of sales people (Mulki et al., 2008).

It is claimed that the underlying motivations of salespeople can be displayed through their approach to customers, some orientated towards selling (SO) in which taking the order is prioritised, while others are more orientated towards finding the right solution for their customers (CO) (Saxe \& Weitz, 1982). When coupled with Adaptive Selling (Weitz et al., 1986) orientation appears to determine sales success or failure, with some claiming that SO behaviours lead to a lack of buyer-seller trust and $\mathrm{CO}$ behaviours, giving rise to the development of mutual trust (Guenzi et al., 2016). Interestingly, the role of the organisation in promoting $\mathrm{SO}$ or $\mathrm{CO}$ behaviour has attracted the attention of scholars, leading to claims that orientation is primarily influenced by firms' sales strategy or sales management, rather than the individual salesperson (Guenzi, 2003; Terho et al., 2015).

Failure to cope with sales failure is, in itself, a potential cause of future failure (Mallin \& Mayo, 2006). Attribution theory appears to provide an explanation of how salespeople cope with failure by making appropriate attributions, then adapting accordingly (Badovick, 1990; Andrea L. Dixon et al., 2003; A. L. Dixon et al., 2001; Teas \& McElroy, 1986). Attribution theory "is based on three assumptions. First, individuals will attempt to assign causes for important instances of behaviour, and when necessary, will seek additional information in 
order to do so. Second, individuals will assign causal explanations in a systematic manor. Finally, the particular cause that an individual attributes to a given event has important consequences for his/her subsequent behaviour" (Teas \& McElroy, 1986, p. 76).

Failure can be attributed to internal causes which, in relation to salespeople, may be a lack of skill or lack of effort. This may produce a positive response whereby the salesperson tries harder to win the next sale. However, failure may also be attributed to external events over which the salesperson feels they have no influence, e.g. poor-quality leads, poor product, incorrect pricing policy, or inappropriate sales strategy. This might produce a negative response, whereby the salesperson believes they cannot change the outcome, and so they do not feel any responsibility to improve their skills or apply more effort (Badovick, 1990; Andrea L. Dixon et al., 2003; A. L. Dixon et al., 2001; Teas \& McElroy, 1986).

Salespeople need the ability and willingness to learn from failure (Johnson, Friend, Rutherford, et al., 2016). Positive organisational support, which is the support that sales managers provide to salespeople, and tolerance of failure by the organisation, may significantly impact the attribution that salespeople apply to their failures and their ability to reflect and learn from both success and failure (Johnson, Friend, Rutherford, et al., 2016). (Dixon \& Schertzer, 2005; Gonzalez et al., 2005; Goodwin et al., 1997; Harmon et al., 2002; Johnson, Friend, Rutherford, et al., 2016; Mayo \& Mallin, 2010).

This review of the motivation of salespeople also identifies that much of the extant literature is relatively dated. Khusainova et al. (2018) excellent review of the motivation literature, for example, identifies 63 noteworthy papers, only 14 less than 8 years old. With technology significantly impacting the nature of sales (Hunter \& Panagopoulos, 2015) and the differing attitudes of younger people towards work and the workplace (see, e.g., Stewart, Oliver, 
Cravens, and Oishi (2017)), it may be prudent to revisit and potentially update theories associated with the techniques, skills, knowledge and motivations of salespeople.

\subsection{Failure of sales management}

Sales managers, however, also have a responsibility to recruit, train, coach and manage their salespeople, for which there is an abundance of literature, perhaps suggesting that studies are keener to explain what should be done to salespeople, rather than the antecedents or detriments of salespeople's motivation.

"No matter what excuses the sales management team might offer for the subpar performer (e.g., dismal economic conditions, intense competition, inadequate selling skills, little initiative or drive), the simple fact of the matter is that the rationale offered can be dispatched with by clearly assigning responsibility to the sales management team" (Dubinsky, 1999, p. 15). As sales managers have input into sales strategy and are responsible for enactment through the salespeople they manage, it could be reasonably assumed that the quality of sales management affects the performance of salespeople (Dubinsky, 1999; Harmon et al., 2002; Ingram et al., 1992). Accordingly, this section looks first at the skills which sales managers need, recommended activities and overall effectiveness. Next attention is directed towards five topics that were identified as potential causes of sales failure by sales practitioners and academics alike, namely recruitment criteria, socialisation, training, workload and controls.

\subsubsection{Attributes}

It may appear axiomatic to state that, to be successful, a sales manager needs to possess the skills and knowledge required to undertake the activities associated with their job role (Plank et al., 2018; Powers et al., 2014). Yet, it appears that little research has been directed towards understanding the role of the sales manager, or the skills and knowledge required to be successful. Furthermore, of particular note is the fact that the attitudes promoted by the sales manager towards customer relationships and selling/customer orientation are transmitted to 
the sales team through the development of close relationships, monitoring and providing feedback to salespeople (Albrecht et al., 2015; Dubinsky, 1999; Malek et al., 2018; Murphy \& Li, 2012; Spillecke \& Brettel, 2013). When coupled with claims that many sales managers are themselves underdeveloped Plank et al. (2018) this suggests sales manager training may be a potential cause of sales failure and an area ripe for future research. While Powers et al. (2014) provide a framework of skills required and Plank et al. (2018) offer a typology of activities (see Table 10), neither present advice on how to evaluate the ability and/or training of a sales manager, nor on how to go about designing and delivering training that would improve performance. Considering the impact that a sales manager can have on the success or failure of their salespeople, as well as the dearth of extant literature that directly addresses said topic, it would appear this is an area in urgent need of attention (Plank et al., 2018).

Table 10: Failure of sales management: Attributes

\begin{tabular}{|c|c|c|}
\hline Key point & Overview of theory & Relevant papers \\
\hline Skills & $\begin{array}{l}\text { Interpersonal, technical and strategic skills are all } \\
\text { required to be an effective sales manager. }\end{array}$ & $\begin{array}{l}\text { (Powers et al., } \\
\text { 2010; Powers et al., } \\
\text { 2014) }\end{array}$ \\
\hline Activities & $\begin{array}{l}\text { Sales managers undertake planning, organising, } \\
\text { selecting methods and tools, training, setting } \\
\text { compensation, and supervision and evaluation of } \\
\text { salespeople. }\end{array}$ & $\begin{array}{l}\text { (Murphy \& Li, } \\
\text { 2012; Plank et al., } \\
\text { 2018; Reid et al., } \\
\text { 2017) }\end{array}$ \\
\hline
\end{tabular}

Sales managers are responsible for managing sales people. The ways in which people are recruited, socialised and trained, coupled with their allocated workload and measures to ensure adherence and compliance (as shown in Table 11) have a considerable impact on their sales success or failure (Dubinsky, 1999; Dubinsky et al., 2001; Harmon et al., 2002; Malek et al., 2018; Piercy et al., 2014; Plank et al., 2018). 


\begin{tabular}{|c|c|c|}
\hline Key point & Overview of theory & Relevant papers \\
\hline Recruitment & $\begin{array}{l}\text { The selection of salespeople is one of the most } \\
\text { important tasks of sales managers. Poor job analysis } \\
\text { and job description, failure to utilise multiple } \\
\text { appropriate selection criteria and failure to calibrate } \\
\text { selection tests against the current salesforce can all } \\
\text { lead to failure. The cost of failure can result from } \\
\text { both direct expenditure to re-hire/train or lost } \\
\text { revenue. }\end{array}$ & $\begin{array}{l}\text { (Dubinsky et al., } \\
\text { 2001; Randall \& } \\
\text { Randall, 2001; } \\
\text { Richardson, 1999) }\end{array}$ \\
\hline Socialisation & $\begin{array}{l}\text { Selling uses physical and emotional energy. It may } \\
\text { create feelings of insecurity. Demands may be } \\
\text { experienced through job activities, learning and } \\
\text { development, targets, goals and performance } \\
\text { reviews. Organisational socialisation techniques } \\
\text { help a new salesperson to learn the skills and } \\
\text { knowledge and develop the psychological resources } \\
\text { needed to navigate their new firm and to perform } \\
\text { their role successfully. Buddying is recommended } \\
\text { as it reinforces formal training and reduces } \\
\text { uncertainty. Furthermore, the allocation of a buddy } \\
\text { is within the sphere of control of a sales manager. }\end{array}$ & $\begin{array}{l}\text { (Albrecht et al., } \\
\text { 2015; Bande et al., } \\
\text { 2015; Commeiras et } \\
\text { al., 2013; Andrea L. } \\
\text { Dixon et al., 2003; } \\
\text { Friend et al., 2016; } \\
\text { Knight et al., 2014; } \\
\text { Miao \& Evans, } \\
\text { 2013; Sager et al., } \\
\text { 2014; Saks \& } \\
\text { Gruman, 2014) }\end{array}$ \\
\hline Training & $\begin{array}{l}\text { Training should be personalised to meet the needs } \\
\text { of the individual and be designed to support their } \\
\text { learning of the skills, knowledge and development } \\
\text { of sufficient experience required to successfully } \\
\text { undertake their role. However, too much training } \\
\text { may reduce the time available for selling, } \\
\text { potentially promoting sales failure. }\end{array}$ & $\begin{array}{l}\text { (Jolson, 1999; Kim } \\
\text { et al., 2013; Kumar } \\
\text { et al., 2014; Lassk et } \\
\text { al., 2012; Loveland } \\
\text { et al., 2015; Singh et } \\
\text { al., 2015) }\end{array}$ \\
\hline Workload & $\begin{array}{l}\text { Territories should be designed to provide only } \\
\text { sufficient market potential to support the quota of } \\
\text { the individual. Inadequate potential may mean } \\
\text { salespeople experience difficulty in achieving their } \\
\text { sales goals. Excessive potential may lead to missed } \\
\text { sales. Moreover, quotas impact the behaviour of } \\
\text { salespeople with hard to achieve targets being more } \\
\text { likely to positively promote SO behaviours as well } \\
\text { as negatively impact entrepreneurial and creative } \\
\text { selling behaviours. }\end{array}$ & $\begin{array}{l}\text { (Dubinsky, 1999; } \\
\text { Miao \& Evans, } \\
\text { 2013; Schwepker \& } \\
\text { Good, 2012; } \\
\text { Spillecke \& Brettel, } \\
\text { 2013) }\end{array}$ \\
\hline $\begin{array}{l}\text { Control \& } \\
\text { motivation }\end{array}$ & $\begin{array}{l}\text { Sales managers can influence the motivation and } \\
\text { behaviours of salespeople through the control } \\
\text { systems which are applied. Higher levels of } \\
\text { competency of the sales manager to enact control } \\
\text { may promote positive outcomes. Training sales } \\
\text { managers may well offer the most effective way to } \\
\text { increase the motivation of salespeople and their } \\
\text { overall performance. }\end{array}$ & $\begin{array}{l}\text { (Khusainova et al., } \\
\text { 2018; Malek et al., } \\
\text { 2018; Piercy et al., } \\
\text { 2014). }\end{array}$ \\
\hline
\end{tabular}


Sales managers are responsible for, or at least significantly involved in, the recruitment and training of salespeople (Dubinsky et al., 2001). There is no substitute for selecting the right candidate (Dubinsky et al., 2001; Randall \& Randall, 2001), with the decision whether or not to hire having long-term consequences for the firm, as "when the sales manager selects a successful candidate, the payoff comes from added sales volume and profits, as well as improved customer relationships. When the sales manager selects a sales candidate who subsequently fails, the results can be dramatically adverse, leading to a host of hazards, threats, and losses" (Dubinsky et al., 2001, p. 17). One such hazard appears to be that it typically takes up to 4 months to replace a salesperson and a further 38 months before the new hire can recover sales revenue to the original level of business (Richardson, 1999).

A wide range of recruitment selection techniques are reported to be used, with no one particular method being most effective (Randall \& Randall, 2001). Indeed, personal interviews, letters of recommendation, reference checks, skills and personality testing, assessment centres and simulations, use of biographical information, personal appearance and even the use of blood tests appear to offer clues about the personality and capability of applicants (Randall \& Randall, 2001). With such a wide battery of tests from which to select, it is essential that job analysis offers clear specifications that defines the attributes required to be successful in the role.

Once a salesperson has been recruited, they need to become familiar with the norms of their new organisation and learn how to successfully operate within their new firm. Much has been written about the process of organisational socialisation (OS), through which new salespeople learn the skills required and develop the psychological resources needed to perform their role successfully. While most literature is generalised and applies to a wide variety of job roles (see, e.g., Saks and Gruman (2014)), the sales situation is discussed by Sager et al. (2014), 
who claim that serial socialisation tactics, which include the provision of a role model and availability of sales training to new hires, are of particular importance.

Sales managers need to be cognisant that selling uses both physical and emotional energy. It may create feelings of insecurity, role ambiguity and role stress (Miao \& Evans, 2013).

Demands may be experienced through job activities, learning and development, targets, goals and performance reviews (Albrecht et al., 2015). Salespeople need to build PsyCap selfefficacy through learning (Knight et al., 2014), develop hope in the form of personal motivation to hit sales targets, optimism to succeed, and resilience to bounce back from setbacks (Bande et al., 2015).

Buddying has been shown to reduce the time it takes a new hire to become successful by supporting formalised training and reducing uncertainty (Commeiras et al., 2013; Andrea L. Dixon et al., 2003). As the selection of the buddy and overseeing the process can be managed directly, it would appear sales managers have the control and resources needed to successfully support their salespeople through organisational entry. Furthermore, the literature suggests the more training provided within the first six months the better, providing what is delivered is personalised to support both the job role and takes account of the prior experience of the new salesperson (Lassk et al., 2012; Loveland et al., 2015; Singh et al., 2015). Conversely, too much opt-in or discretionary training may reduce selling time and thus negatively affect sales success (Jolson, 1999; Kumar et al., 2014).

The way a sales manager allocates work may impact the motivation and behaviours of their salespeople. Territory design, workload allocation, quotas and evaluation processes to ensure compliance, were identified as topics of interest and impact (Dubinsky, 1999). If territories are designed with inadequate potential, sales personnel may experience difficulty in achieving their sales goals. A workload which is too onerous may mean salespeople are 
unable to keep up with the demands of their job (Dubinsky, 1999); add to that a sales management focus on hitting quotas, and SO behaviours may be promoted (Schwepker \& Good, 2012). Furthermore, entrepreneurial orientation and the ability/motivation to find creative solutions may also be reduced (Spillecke \& Brettel, 2013). Yet, excessive potential may lead to lower productivity and missed sales (Dubinsky, 1999)

The form of control favoured by sales management may directly influence the motivation and behaviours of salespeople (Khusainova et al., 2018; Malek et al., 2018; Piercy et al., 2014). While a host of motivation theory has been posited to explain the motivations of salespeople it would appear they are most affected by the control systems enacted by sales management (Malek et al., 2018). Two control systems are predominantly discussed in relation to the activities of salespeople, namely behaviour control and outcome control. Behavioural controls define the way a salesperson should work, then monitor compliance with the process. Alternatively, outcome control holds the salesperson accountable for their results (Malek et al., 2018). Controls may also be considered as formal, whereby the organisation defines standards and ensures compliance, and informal, which relates to the unwritten norms of the organisation, as self-determined by the individual and how they relate to their peers, wider professional standards and culture (Malek et al., 2018). Whichever control system is used, it relies on the competency of the sales manager to enact it (Piercy et al., 2014). This suggests that, to avoid sales failure, the level of competency of the sales manager should be identified and, where necessary, additional training and support provided (Piercy et al., 2014).

\subsection{How to avoid sales failure}

This review of literature identifies that while there are few papers that directly address sales failure, the wider corpus of academic literature provides various clues as to the underlying causes. Categorising sales failure into failures caused by sales strategy, salespeople and sales 
management therefore provides a useful lens for further investigation. By synthesising the 104 papers pertaining to potential causes of sales failure, it has therefore been possible to offer practitioners and scholars a detailed, structured, picture of the current state of literature in relation to each of the identified themes, sub-themes and topics identified in this review.

Hitherto, literature appears to describe failure and success in simplistic, uni-variable, terms. Consideration of the impact, however, of the sales failure inherent in successfully taking an order from a customer who fails to fit the strategic aims of the organisation, suggests that a more nuanced understanding is required, particularly given that salespeople and sales managers may accept failure as a part of their role (Fine, 2007; Morris et al., 1994).

A single failure event or even combination of failures, may not of itself lead to complete sales failure in the short term. Identification of sub-optimal performance, however, may be useful in terms of identifying why an organisation is failing to achieve its maximum sales potential. Furthermore, whilst achieving a sale may be an acceptable short-term situation for a firm, clearly a failure to reach maximum sales potential in terms of achieving sales strategy through optimal sales management activities and the most appropriate sales effort may lead to negative longer-term consequences. One example may be the exploitation of missed opportunities by competitors, who may then capture additional sales revenues for themselves. Clearly losing sales to competition is likely to lead to a smaller overall market share, leading to lower growth and profits and reduced ability to reinvest into new products, services or infrastructure.

Whilst agreeing that a level of sales failure is to be expected, though not desirable (Fine, 2007; Morris et al., 1994), selling organisations need to constantly improve their competitiveness. Therefore, this paper concludes that identification and measurement of different types of sales failure is required, so that an organisation is able to both measure and 
visualise the distance that its salesforce is from overall sales failure . Areas of deficit could then be identified enabling corrective action to be undertaken as required. Through conceptual deduction (Meredith, 1993), new relationships and a framework is proposed as shown in figure 2.

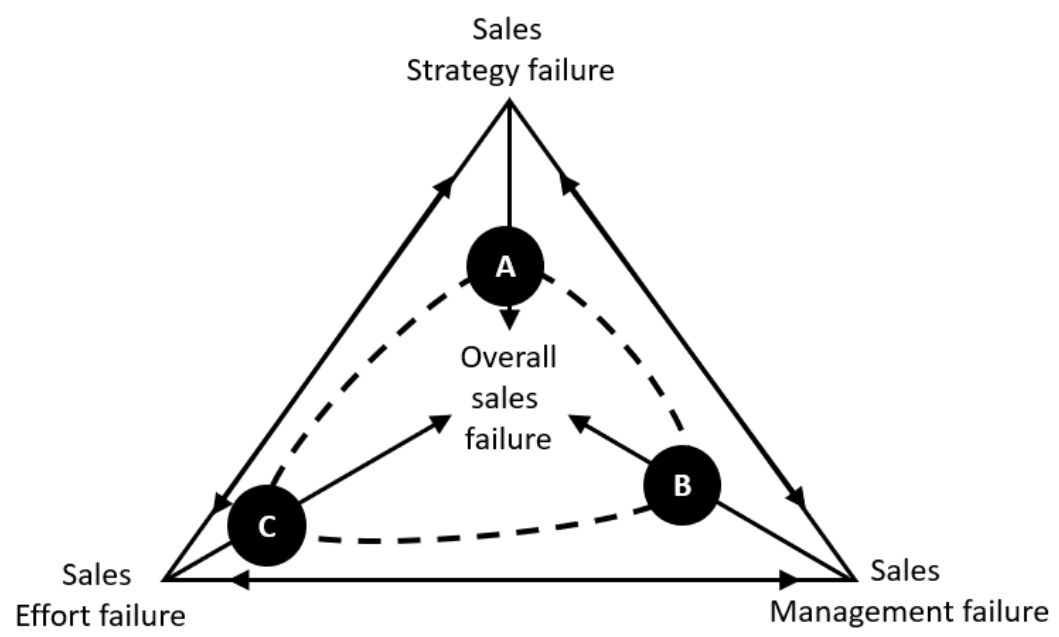

Figure 2: Proposed framework for measuring overall sales failure

Overall sales failure is a formative construct, made up of three broad variables, their combination determining where on the three dimensional "sales failure" scale an organisation sits. Extant literature appears to imply, for example, that relationships between the strategy of the selling firm, and how it is enacted by sales management, leads to the customer experience delivered through interaction with salespeople (Cron et al., 2014; Terho et al., 2015).

This suggests that the relationships illustrated in the framework would be as follows: sales effort failure refers to the level of failure experienced in respect of the techniques applied, skills, knowledge, motivation and actions of salespeople as experienced by customers. As salespeople work on the boundary between customer and supplier, it is their actions (or inactions) to create sales opportunities and obtain orders from customers, that may positively promote or negatively impact sales failure (Friend et al., 2014; Mallin \& Mayo, 2006; Mayo \& Mallin, 2010). 
Selling strategy failure refers to the level of failure measured in respect of the combination of customer segmentation, prioritising and targeting, selection of relationship models and the use of selling channels, all of which determine the way in which a firm engages with customers (Cron et al., 2014). Therefore, strategic decisions relating to the selection of customer segments, channels and prioritisation of customers, could mediate sales failure, as without a clearly defined and articulated strategy, sales effort may not be applied effectively (Terho et al., 2015). Furthermore, this would suggest that the selling effort of salespeople is itself mediated by the selling strategy.

Sales management failure refers to the level of failure measured in respect of the skills and activities of the sales manager. As sales managers oversee selection, socialisation and training, allocation of workload, systems of control and the resultant motivation of salespeople (Dubinsky, 1999), it would appear that they enact sales strategy through the appropriate allocation of sales effort (Dubinsky, 1999; Dubinsky et al., 2001; Harmon et al., 2002; Malek et al., 2018; Piercy et al., 2014; Plank et al., 2018). This suggests that the actions of sales management mediate selling effort and consequently sales success. Furthermore, it is reasonable to assume that sales managers provide strategic input to the senior management of their firm, as they are able to garner feedback from both salespeople and their customers. This suggests that sales management not only mediate sales effort directly, but also indirectly through their input into sales strategy.

An example of how the proposed framework for the measurement of overall sales failure could be applied, is represented in figure 2 as points $\mathrm{A}, \mathrm{B}$ and $\mathrm{C}$ with a dotted line representing the total area of sales failure that is being experienced by the organisation. Point A represents the level of failure measured for sales strategy. In this example, it could be that the organisation has failed to segment and target customers using all available and appropriate channels. This failure may not be detectable using the traditional method of 
managing sales success using the percentage of quota achieved. Yet, it may still have a longterm negative impact on the organisation as competitors may exploit this weakness by targeting the organisation's current or potential customers, using channels not being supported. Point B represents the level of failure measured for sales management. This could, for example, represent the failure of sales management to fairly allocate workload and use appropriate control mechanisms to maximise revenue potential. The sales team may be achieving their sales quotas, but failure to maximise potential may carry long term negative consequences for the organisation as some overworked salespeople may leave and/or underworked salespeople would not be being stretched to maximise revenue from their territory, leaving opportunity for competitors. Point $\mathrm{C}$ represents the level of failure measured in respect of selling effort. In this example, sales quotas are generally being achieved, but salespeople may still be deemed to be failing in respect of the level of activity or effort needed to achieve the required level of sales, costs of sales being higher than necessary. This is illustrated by point $C$ not being at the very top of the scale, as some level of failure is still present. What this example shows is that while literature posits success and failure as binary events, it may in fact be a more nuanced process. The proposed framework therefore, contributes to knowledge as, to the best of our knowledge, it is the first time that such a method to measure overall sales failure has been presented.

\section{Future research directions}

Based on the findings of this paper, it would appear that there is the opportunity to further investigate all three of the themes identified, namely failure of sales strategy, failure of salespeople and failure of sales management. Additionally, future research into the measurement of overall sales failure directed toward development of a more nuanced understanding would be of interest to scholars and practitioners alike. Additionally, two key constructs, namely those of firm size and ICT/IM usage (Claycomb et al., 2005; Ellegaard, 
2009; Khusainova et al., 2018) appear to be under researched in respect of sales. It would stand to reason that the larger the organisation, the greater the available resources that could be directed towards determining sales strategy and management of the sales team. Therefore, a better understanding of how a smaller firm might arrange scares resources so as to reduce their propensity towards sales failure, would be of interest to academics and practitioners alike. The issue of resource restriction and lack of buying experience (Ellegaard, 2006) may in turn also lead to a small firm owner manager having using different decision making criteria when making purchasing decisions (McGowan, 2018).

Furthermore, the impact of ICT/IM usage on businesses to business communications is clearly significant (Khusainova et al., 2018). Yet, the impact is unknown. With no apparent let-up in the speed of technological change, further research is recommended to determine if such methods of communication are beneficial or detrimental when used in a selling situation. All this leads to a number of potentially interesting topics for future research, as shown in table 12.

Table 12: Topics for future research

\begin{tabular}{|l|l|}
\hline Future research topic & Areas of interest \\
\hline Failure of sales strategy & $\begin{array}{l}\text { Are the purchasing decision criteria of a small firm buyer } \\
\text { different to those of a larger firm and if so, how can a sales } \\
\text { organisation be best arranged to win the business? }\end{array}$ \\
\cline { 2 - 2 } & $\begin{array}{l}\text { How can a small firm most effectively apply limited sales } \\
\text { resources to meet its strategic objectives? }\end{array}$ \\
\hline Failure of salespeople & $\begin{array}{l}\text { What is the impact on career aspirations and future outcomes } \\
\text { for salespeople who fail in a sales role? }\end{array}$ \\
\cline { 2 - 2 } & $\begin{array}{l}\text { How can salespeople and their managers effectively use } \\
\text { Instant Messaging tools (e.g. WhatsApp, WeChat and Slack) } \\
\text { within their organisations? }\end{array}$ \\
\cline { 2 - 2 } & \begin{tabular}{l} 
Does firm size impact the use of Instant Messaging tools \\
within a sales context? \\
\cline { 2 - 2 }
\end{tabular} \\
$\begin{array}{l}\text { What is the impact of using Instant Messaging on the quality } \\
\text { of buyer-seller relationships and/or the work-life balance of } \\
\text { people involved? }\end{array}$ \\
\hline
\end{tabular}




\begin{tabular}{|c|c|}
\hline \multirow[t]{2}{*}{$\begin{array}{l}\text { Failure of sales } \\
\text { management }\end{array}$} & $\begin{array}{l}\text { All areas of sales management appear to be under researched. } \\
\text { For a framework of sales management skills see Powers et al. } \\
\text { (2014) and for a typology of activities see Plank et al. } \\
\text { (2018). }\end{array}$ \\
\hline & $\begin{array}{l}\text { What is the impact on overall performance of a sales manager } \\
\text { lacking credibility, vision, strong decision-making skills and } \\
\text { the ability to manage upwards? }\end{array}$ \\
\hline \multirow[t]{4}{*}{ Overall sales failure } & $\begin{array}{l}\text { How do the constructs of failure of sales strategy, failure of } \\
\text { the salesperson and failure of sales management combine to } \\
\text { promote overall sales failure? }\end{array}$ \\
\hline & $\begin{array}{l}\text { Do failures of sales strategy, the salesperson and sales } \\
\text { management impact overall sales failure equally? Is a } \\
\text { weighted numerical scale or other device needed to enable } \\
\text { organisations to better measure their distance from overall } \\
\text { sales failure and areas in need of improvement? }\end{array}$ \\
\hline & $\begin{array}{l}\text { What is the impact of firm size on the measurement of overall } \\
\text { sales failure? }\end{array}$ \\
\hline & $\begin{array}{l}\text { Does use of ICT or Instant Messaging in buyer-seller } \\
\text { relationships impact overall sales failure? }\end{array}$ \\
\hline
\end{tabular}

\subsection{Future research into the failure of sales strategy}

Extant literature in respect of selling, for example, appears not to have identified firm size as an important construct, while this has been identified as an important construct by literature related to purchasing. "Small company owners suffer from limited purchasing experience. They are not educated buyers, but rather self-taught producers... [and] they rely on subjective (or even unprofessional) criteria when selecting suppliers" (Ellegaard, 2006, p. 280).

Differences between small and large firms appear to include relationship length (Paik, 2011), expertise (Beekman \& Robinson, 2004) who buys (owner-manager of professional buyer) and buying criteria (Ellegaard, 2009). These differences would suggest that the sales techniques and organisation of the sales force (i.e. sales management) may well need to be adapted to meet the needs of the customer (Rackham, 1988; Weitz et al., 1986). Yet, is adaptation for one customer the appropriate response, or should there be a sales strategy that approaches this segment differently? While it is claimed small firms could be segmented and managed as transactional customers (Sharma, 2007), the customer may use the quality and 
form of the supplier relationship as a buying criterion (McGowan, 2018). This difference in perspective from the buyer side of the dyad suggests that further research in this area is needed.

Furthermore, the construct of firm size could be considered in two ways: first, how to sell to small firms and, secondly, which strategies small firms themselves should use. Questions may include: Do small companies wish to use different channels through which to buy? Which channels offer the best potential and are most cost effective when servicing small firms? Does the size of the firm make a difference to the strategy and channels that could or should be used? What are the options, antecedents to success and detriments that may affect a selling firm, based upon its size?

\subsection{Future research into failure of salespeople}

In respect of research into the performance of salespeople, it would appear that, to date, scholars have primarily used samples which include people currently in a sales role. Yet, to fully understand sales failure, it may be that people subsequently change company, but stay in a sales role, or transition into one that does not require selling skills. With this in mind, future research could perhaps consider focusing studies on salespeople who have moved company following a failure or have transitioned into another sort of role. Questions for future research may include: Does failure in one selling role lead to subsequent failure in another company? Does the attribution of failure made by the salesperson (e.g. from external attribution to internal) change post-failure in a sales role? If failed salespeople transition to a new role, do these roles require knowledge of skills? Are any roles particularly suitable for a failed salesperson? Is there any silver lining for the salesperson who fails? For example, does experiencing failure in a sales role develop emotional intelligence or psychological capital? 
Almost everybody has been impacted by the dramatic changes in ICT that have occurred in the last 20 years or so (Fensel et al., 2014). Yet, while there has been considerable attention paid to Customer Relationship Management software (CRM), technology readiness and adoption models, and some attention paid to the use of platforms (e.g. LinkedIn, Twitter, Facebook, Skype and WebEx) (Khusainova et al., 2018), it would appear that little attention has been paid to the impact of such technology in respect of buyer-seller relationships. The impact of constant connectivity with the potential for an always-on culture could well impact both sides of the buyer-seller dyad. This raises a number of questions for future research including: How do salespeople and their managers effectively use the aforementioned ICT and Instant Messaging (IM) tools (e.g. WhatsApp, WeChat and Slack) within their organisations? What are the antecedents, detriments and consequences of using IM to communicate with customers? Are buyers already using IM tools and, if so, what are salespeople's expectations of the use of said tools? What are the impacts in respect of motivation, stress and propensity to stay or leave a sales role? Are there any legal implications for individuals or organisations? Furthermore, does firm size affect adoption of ICT/IM tools, e.g. is adoption easier in a small firm situation and can they find competitive advantage through the use of such tools or is ICT/IM of more use to a larger firm?

\subsection{Future research into failure of sales management}

Sales management generally appears to be a very under-researched topic (Dubinsky, 1999; Dubinsky et al., 2001). Building on the framework of skills required (Powers et al., 2014) and typology of activities Plank et al. (2018), there would appear to be are opportunities to further investigate all of the sales management activities identified in this review. Literature in respect of sales management evaluation, specifically the ability and training of a sales manager appears to be lacking. Considering the impact that a sales manager can have on the success or failure of the overall sales organisation this would appear to be an area in urgent 
need of attention (Plank et al., 2018). Moreover, and as previously mentioned, the use of ICT/IM tools has the potential to significantly change communication between manager and salesperson as well as between buyer and seller. Additionally, four areas of sales failure in respect of sales managers were suggested at both the practitioner and academic conferences but not included in this paper due to a lack of extant literature. These are: lack of credibility, lack of vision, inability to manage upwards and weak decision making. These four topics appear to be under-researched in this context, suggesting that future research would be of considerable interest to academics and practitioners alike.

\subsection{Future research into overall sales failure}

Future research into the proposed framework for the measurement of overall sales failure could be conducted to investigate how the variables of sales strategy, sales management and sales effort combine to promote sales failure. Attention could also be directed to further identifying sub-constructs. Furthermore, at this stage it would appear that all three variables of sales strategy, sales management and selling effort are relevant. Future work could also be directed towards determining if the contribution of each construct is of equal importance or if a weighted measure is required. Additionally, development of a numerical scale or formula, or other device that enabled an organisation to numerically measure their distance from overall sales failure, would be of use to scholars and practitioners alike. While the framework presented in Figure 2 is conceptualised at the highest order construct (Meredith, 1993), it may also be interesting to identify whether there are direct or indirect relationships between the sub-themes and topics presented in the present paper, as this may provide a deeper understanding of the antecedents of sales failure. Future research be conducted to investigate how the variables of sales strategy, sales management and sales effort combine to promote overall sales failure. Attention could be directed to further identifying sub-constructs. Furthermore, at this stage it would appear that all three variables of sales strategy, sales 
management and selling effort are relevant. However, further work could be directed to determine if the contribution of each is equal or if a weighted measure is required.

Additionally, development of a numerical scale or formula, or other device that enabled an organisation to numerically measure their distance from overall sales failure would be of use to scholars and practitioners alike.

Additionally, the impact of firm size and ICT/IM usage potentially influence sales strategy, selling effort, and sales management, leading to an amended framework presented in Figure 3. Future research to explore this framework could address a number of questions including: Does firm size or ICT directly or indirectly impact sales strategy, sales management or selling effort? If so, do they affect each element equally? Furthermore, does the size of the firm determine the speed of ICT adoption? Is ICT adoption by salespeople situation-specific, e.g. related to the industry sector, geography or age of the salesperson/customer? Additionally, considering the size of the firm and the overall impact of sales failure upon it, to what extent does one failure impact future failures? Does speed of failure determine future outcomes? Does firm size impact reacquisition of lost sales? 


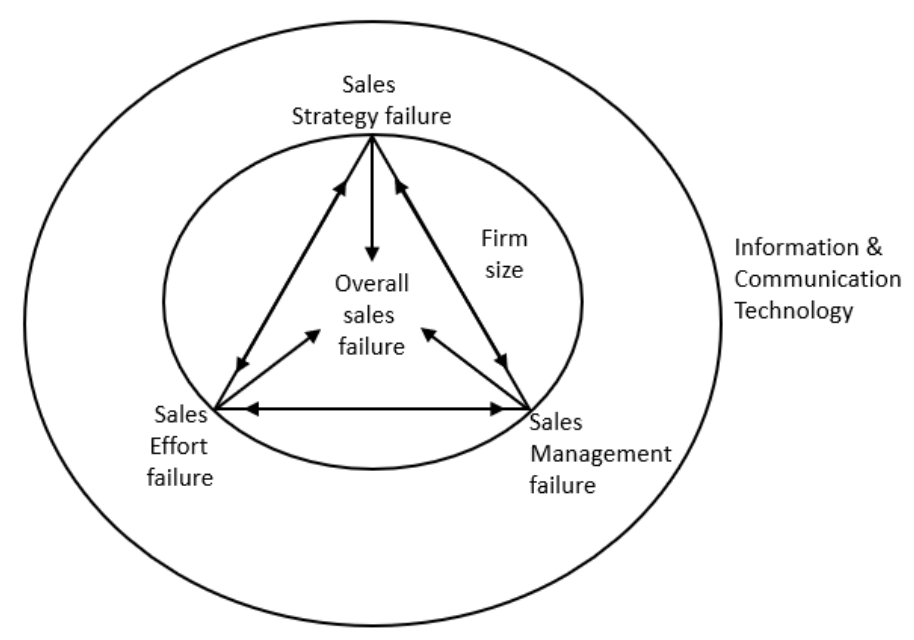

Figure 3: The effect of firm size and ICT/IM usage on overall sales failure

\section{Conclusion}

The above-mentioned aim of this article was to review the state of literature in respect of sales failure. Three key themes, namely selling strategy, salesperson and sales management, were identified. These were further broken down into 8 sub-themes, which incorporated 36 topics of interest. A discussion of each was presented, with the findings showing that while there is a substantial body of literature that describes the antecedents of success, there is little that relates directly to sales failure. Furthermore, the findings suggest that it is possible to succeed in selling, yet still to fail overall, both in relative and absolute terms. An example of this is successfully selling to a customer who does not fit the strategic aims of the business. Additionally, while short-term success may be experienced, there may be longer-term negative consequences, leading to overall sales failure. All of this leads to the suggestion that a more nuanced understanding is required. Accordingly, a framework for the measurement of overall sales failure is presented. Consideration is given to the impact of failures of sales strategy, sales management and selling effort. These appear to combine to determine the level of overall sales failure that is experienced by an organisation. 
Considering the impact of technology on selling (Khusainova et al., 2018), it is surprising to find that literature also appears not to have considered the impact of IM technology on the relationships that sales managers have with their salespeople and/or salespeople with their customers. Future research is recommended to further develop knowledge in this area.

While buying literature appears to have identified differences in buyer behaviour based upon firm size (Ellegaard, 2006, 2009), this distinction seems to have been largely ignored by sales scholars. Firm size could be considered in relation to both sides of the buyer-seller dyad. Although no one standard definition of firm size exists (Reynolds et al., 2005) if the micro, small, medium and large firms, as used by the European Commission ("The new SME definition," 2016), were to be adopted, then 16 combinations of the buyer-seller dyad could be considered in future research, leading to more nuanced findings. 


\section{References}

Adisa, T. A., Gbadamosi, G., \& Osabutey, E. L. C. (2017). What happened to the border? The role of mobile information technology devices on employees' work-life balance. Personnel Review, 46(8), 1651-1671. doi:doi:10.1108/PR-08-2016-0222

Albrecht, S. L., Bakker, A. B., Gruman, J. A., Macey, W. H., \& Saks, A. M. (2015). Employee engagement, human resource management practices and competitive advantage: An integrated approach. Journal of Organizational Effectiveness: People and Performance, 2(1), 7-35. doi:http://dx.doi.org/10.1108/JOEPP-08-2014-0042

Badovick, G. J. (1990). Emotional reactions and salesperson motivation: An attributional approach following inadequate sales performance. Journal of the Academy of Marketing Science, 18(2), 123130.

Bande, B., Fernández-Ferrín, P., Varela, J. A., \& Jaramillo, F. (2015). Emotions and salesperson propensity to leave: The effects of emotional intelligence and resilience. Industrial Marketing Management, 44, 142-153. doi:10.1016/j.indmarman.2014.10.011

Baumann, J., Le Meunier-FitzHugh, K., \& Wilson, H. (2017). The challenge of communicating reciprocal value promises: Buyer-seller value proposition disparity in professional services. Industrial Marketing Management, 64, 107-121. doi:10.1016/j.indmarman.2017.02.002

Beekman, A. V., \& Robinson, R. B. (2004). Supplier partnerships and the small, high-growth firm: Selecting for success. Journal of Small Business Management, 42(1), 59-77. doi:10.1111/j.1540627X.2004.00097.x

Boejgaard, J., \& Ellegaard, C. (2010). Unfolding implementation in industrial market segmentation. Industrial Marketing Management, 39(8), 1291-1299. doi:10.1016/j.indmarman.2010.06.004

Bolander, W., Zahn, W. J., Loe, T. W., \& Clark, M. (2015). Managing New Salespeople's Ethical Behaviors during Repetitive Failures: When Trying to Help Actually Hurts. Journal of Business Ethics, 144(3), 519-532. doi:10.1007/s10551-015-2817-8

Braun, V., \& Clarke, V. (2006). Using thematic analysis in psychology. Qualitative Research in Psychology, 3(2), 77-101. doi:10.1191/1478088706qp063oa

Bygballe, L. E. (2016). Toward a conceptualization of supplier-switching processes in business relationships. Journal of Purchasing and Supply Management, in Press. doi:http://dx.doi.org/10.1016/i.pursup.2016.04.007

Chia-Chi, C. (2006). When service fails: The role of the salesperson and the customer. Psychology \& Marketing, 23(3), 203-224. doi:10.1002/mar.20096

Claycomb, C., lyer, K., \& Germain, R. (2005). Predicting the level of b2b e-commerce in industrial organizations. Industrial Marketing Management, 34(3), 221-234. doi:10.1016/j.indmarman.2004.01.009

Commeiras, N., Loubes, A., \& Bories-Azeau, I. (2013). Identification of organizational socialization tactics: The case of sales and marketing trainees in higher education. European Management Journal, 31(2), 164-178. doi:https://doi.org/10.1016/j.emj.2012.05.002 
Cron, W. L., Baldauf, A., Leigh, T. W., \& Grossenbacher, S. (2014). The strategic role of the sales force: Perceptions of senior sales executives. Journal of the Academy of Marketing Science, 42(5), 471-489. doi:10.1007/s11747-014-0377-6

Cuevas, J. M., Julkunen, S., \& Gabrielsson, M. (2015). Power symmetry and the development of trust in interdependent relationships: The mediating role of goal congruence. Industrial Marketing Management, 48, 149-159. doi:10.1016/j.indmarman.2015.03.015

Davies, I. A., \& Ryals, L. J. (2014). The effectiveness of Key Account Management practices. Industrial Marketing Management, 43(7), 1182-1194. doi:10.1016/j.indmarman.2014.06.007

DeCarlo, T. E., Agarwal, S., \& Vyas, S. B. (2007). Performance Expectations of Salespeople: The Role of Past Performance and Causal Attributions in Independent and Interdependent Cultures. Journal of Personal Selling \& Sales Management, 27(2), 133-147. doi:10.2753/pss0885-3134270202

Dibb, S. (1998). Market segmentation: strategies for success. Marketing Intelligence \& Planning(7), 394. doi:10.1108/02634509810244390

Dibb, S., Simkin, L., \& Wilson, D. (2008). Diagnosing and treating operational and implementation barriers in synoptic marketing planning. Industrial Marketing Management, 37(5), 539-553. doi:10.1016/j.indmarman.2007.08.002

Dixon, \& Schertzer, S. M. B. (2005). Bouncing back: How salesperson optimism and self-efficacy influence attributions and behaviors following failure. Journal of Personal Selling \& Sales Management, 25(4), 361-369. doi:10.1080/08853134.2005.10749070

Dixon, A. L., Spiro, R. L., \& Forbes, L. P. (2003). Attributions and behavioral intentions of inexperienced salespersons to failure: An empirical investigation. Journal of the Academy of Marketing Science, 31(4), 459-467.

Dixon, A. L., Spiro, R. L., \& Jamil, M. (2001). Successful and unsuccessful sales calls: Measuring salesperson attributions and behavioural intentions. Journal of Marketing, 65(3), 64-78.

Dixon, M., \& Adamson, B. (2011). The challenger sale: Penguin Group, New York.

Dubinsky, A. J. (1999). Salesperson failure. Sales management is the key. Industrial Marketing Management, 28(1), 7-17. doi:10.1016/S0019-8501(98)00018-2

Dubinsky, A. J., Jolson, M. A., Anderson, R. E., \& Mehta, R. (2001). Salesperson failure: A case of sales manager risk and responsibility. Risk Management, 3(2), 17-28. doi:10.1057/palgrave.rm. 8240083

Elhafsi, M., Zhi, L., Camus, H., \& Craye, E. (2015). An assemble-to-order system with product and components demand with lost sales. International Journal of Production Research, 53(3), 718-735. doi:10.1080/00207543.2014.920547

Ellegaard, C. (2006). Small company purchasing: A research agenda. Journal of Purchasing and Supply Management, 12(5), 272-283. doi:http://dx.doi.org/10.1016/i.pursup.2006.08.004

Ellegaard, C. (2009). The purchasing orientation of small company owners. The Journal of Business and Industrial Marketing, 24(3-4), 291-300. doi:10.1108/08858620910939831 
Eyuboglu, N., Kabadayi, S., \& Buja, A. (2017). Multiple channel complexity: Conceptualization and measurement. Industrial Marketing Management, 65, 194-205. doi:10.1016/j.indmarman.2017.03.010

Fensel, A., Toma, I., García, J. M., Stavrakantonakis, I., \& Fensel, D. (2014). Enabling customers engagement and collaboration for small and medium-sized enterprises in ubiquitous multi-channel ecosystems. Computers in Industry, 65(5), 891-904. doi:10.1016/j.compind.2014.02.001

Fine, L. M. (2007). Selling and sales management. Business Horizons, 50(3), 185-191. doi:http://dx.doi.org/10.1016/j.bushor.2007.01.001

Friend, S. B., Curasi, C. F., Boles, J. S., \& Bellenger, D. N. (2014). Why are you really losing sales opportunities? A buyers' perspective on the determinants of key account sales failures. Industrial Marketing Management, 43(7), 1124-1135. doi:10.1016/j.indmarman.2014.06.002

Friend, S. B., Johnson, J. S., Luthans, F., \& Sohi, R. S. (2016). Positive Psychology In Sales: Integrating Psychological Capital. Journal of Marketing Theory and Practice, 24(3), 306-327. doi:10.1080/10696679.2016.1170525

Fürst, A., Leimbach, M., \& Prigge, J.-K. (2017). Organizational multichannel differentiation: An analysis of its impact on channel relationships and company sales success. Journal of Marketing, 81(1), 59-82. doi:10.1509/jm.14.0138

Gonzalez, G. R., Hoffman, K. D., \& Ingram, T. N. (2005). Improving relationship selling through failure analysis and recovery efforts: A framework and call to action. Journal of Personal Selling \& Sales Management, 25(1), 57-65.

Gonzalez, G. R., Hoffman, K. D., \& Ingram, T. N. (2014). The sales recovery audit: Learning to walk the talk. Industrial Marketing Management, 43(1), 146-154. doi:http://dx.doi.org/10.1016/j.indmarman.2013.08.004

Goodwin, C., Mayo, M., \& Hill, R. P. (1997). Salesperson Response to Loss of a Major Account: A Qualitative Analysis. Journal of Business Research, 40(2), 167-180.

Groza, M. D., Locander, D. A., \& Howlett, C. H. (2016). Linking thinking styles to sales performance: The importance of creativity and subjective knowledge. Journal of Business Research, 69(10), 41854193. doi:10.1016/j.jbusres.2016.03.006

Guenzi, P. (2003). Antecedents and consequences of a firm's selling orientation. European Journal of Marketing, 37(5/6), 706-727. doi:10.1108/03090560310465116

Guenzi, P., De Luca, L. M., \& Spiro, R. (2016). The combined effect of customer perceptions about a salesperson's adaptive selling and selling orientation on customer trust in the salesperson: $A$ contingency perspective. Journal of Business \& Industrial Marketing, 31(4), 553-564. doi:10.1108/JBIM-02-2015-0037

Hansen, J. D., Lund, D. J., \& DeCarlo, T. E. (2016). A process model of buyer responses to salesperson transgressions and recovery efforts: the impact of salesperson orientation. Journal of Personal Selling \& Sales Management, 36(1), 59-73. doi:10.1080/08853134.2016.1149352

Harmon, H. A., Brown, G., Widing, R. E., \& Hammond, K. L. (2002). Exploring the sales manager's feedback to a failed sales effort. Journal of Business \& Industrial Marketing, 17(1), 43-55. 
Harzing, A.-W. (2013). A preliminary test of Google Scholar as a source for citation data: a longitudinal study of Nobel prize winners. Scientometrics, 94(3), 1057-1075. doi:10.1007/s11192-012-0777-7

Harzing, A.-W., \& Alakangas, S. (2016). Google Scholar, Scopus and the Web of Science: a longitudinal and cross-disciplinary comparison. Scientometrics, 106(2), 787-804. doi:10.1007/s11192-015-1798-9

Heidenreich, S., Wittkowski, K., Handrich, M., \& Falk, T. (2014). The dark side of customer co-creation: Exploring the consequences of failed co-created services. Journal of the Academy of Marketing Science, 43(3), 279-296. doi:10.1007/s11747-014-0387-4

Heidenreich, S., Wittkowski, K., Handrich, M., \& Falk, T. (2015). The dark side of customer co-creation: exploring the consequences of failed co-created services. Journal of the Academy of Marketing Science, 43(3), 279-296. doi:10.1007/s11747-014-0387-4

Homburg, C., Droll, M., \& Totzek, D. (2008). Customer prioritization: Does it pay off, and how should it be implemented? Journal of Marketing, 72(5), 110-130. doi:10.1509/jmkg.72.5.110

Hunter, G. K., \& Panagopoulos, N. G. (2015). Commitment to technological change, sales force intelligence norms, and salesperson key outcomes. Industrial Marketing Management, 50, 162-179. doi:10.1016/j.indmarman.2015.03.023

Ingram, T. N., Schwepker, C. H., \& Hutson, D. (1992). Why Salespeople Fail. Industrial Marketing Management, 21(3), 225-230. doi:Doi 10.1016/0019-8501(92)90019-P

Jaramillo, F., Locander, W. B., Spector, P. E., \& Harris, E. G. (2007). Getting the Job Done: The Moderating Role of Initiative on the Relationship Between Intrinsic Motivation and Adaptive Selling. Journal of Personal Selling \& Sales Management, 27(1), 59-74. doi:10.2753/PSS0885-3134270104

Johnson, J. S., Friend, S. B., \& Malshe, A. (2016). Mixed interpretations of sales proposal signals. Journal of Personal Selling \& Sales Management, 36(3), 264-280. doi:10.1080/08853134.2016.1205447

Johnson, J. S., Friend, S. B., Rutherford, B. N., \& Hamwi, G. A. (2016). Absolute versus relative sales failure. Journal of Business Research, 69(2), 596-603. doi:10.1016/j.jbusres.2015.05.015

Johnston, M. W., Hair Jr, J. F., Boles, J., \& Kurtz, D. L. (1989). Why do salespeople fail? Journal of Personal Selling \& Sales Management, 9(3), 53.

Jolson, M. A. (1999). When salespeople fail: Assessing blame. Industrial Marketing Management, 28(1), 19-26. doi:http://dx.doi.org/10.1016/S0019-8501(98)00019-4

Kabadayi, S. (2011). Choosing the right multiple channel system to minimize transaction costs. Industrial Marketing Management, 40(5), 763-773. doi:10.1016/j.indmarman.2011.02.002

Kabadayi, S., Eyuboglu, N., \& Thomas, G. P. (2007). The performance implications of designing multiple channels to fit with strategy and environment. Journal of Marketing, 71(4), 195-211.

Kaynak, E., Kara, A., Chow, C. S. F., \& Laukkanen, T. (2016). Role of adaptive selling and customer orientation on salesperson performance: Evidence from two distinct markets of europe and asia. Journal of Transnational Management, 21(2), 62-83. doi:10.1080/15475778.2016.1166999

Khusainova, R., Jong, A. d., Lee, N., Marshall, G. W., \& Rudd, J. M. (2018). (Re) defining salesperson motivation: current status, main challenges, and research directions. Journal of Personal Selling \& Sales Management, 38(1), 2-29. doi:10.1080/08853134.2017.1415761 
Kim, J., Lee, A., \& Ryu, H. (2013). Personality and its effects on learning performance: Design guidelines for an adaptive e-learning system based on a user model. International Journal of Industrial Ergonomics, 43(5), 450-461. doi:10.1016/j.ergon.2013.03.001

Knight, P., Mich, C. C., \& Manion, M. T. (2014). The Role of Self-Efficacy in Sales Education. Journal of Marketing Education, 36(2), 156-168.

Kothandaraman, P., Dingus, R. E., \& Agnihotri, R. (2014). Pursuing success in service recovery: A conceptual framework of salesperson's power in selling centre. Journal of Services Research, 14(1), 141-159.

Kumar, V., Sunder, S., \& Leone, R. P. (2014). Measuring and managing a salesperson's future value to the firm. Journal of Marketing Research (JMR), 51(5), 591-608. doi:DOI 10.1509/jmr.13.0198

LaForge, R. W., Ingram, T. N., Hoffman, K. D., \& Gonzalez, G. R. (2010). Sales Organization Recovery Management and Relationship Selling: A Conceptual Model and Empirical Test. Journal of Personal Selling \& Sales Management, 30(3), 223-238. doi:10.2753/pss0885-3134300303

Lapoule, P., \& Colla, E. (2016). The multi-channel impact on the sales forces management. International Journal of Retail \& Distribution Management, 44(3), 248-265. doi:doi:10.1108/IJRDM11-2014-0159

Lassk, F. G., Ingram, T. N., Kraus, F., \& Mascio, R. D. (2012). The Future of Sales Training: Challenges and Related Research Questions. Journal of Personal Selling \& Sales Management, 32(1), 141-154. doi:10.2753/PSS0885-3134320112

Leach, M. P., \& Liu, A. H. (2014). It ain't over 'til it's over: Evaluating reacquisition opportunities in business-to-business markets. Industrial Marketing Management, 43(4), 573-581. doi:10.1016/j.indmarman.2014.02.010

Lindh, C., \& Nordman, E. R. (2017). Information technology and performance in industrial business relationships: the mediating effect of business development. Journal of Business \& Industrial Marketing, 32(7), 998-1008. doi:10.1108/Jbim-12-2016-0282

Liu, H., Liu, L., \& Liu, N. (2013). Review: Risk evaluation approaches in failure mode and effects analysis: A literature review. Expert Systems With Applications, 40, 828-838. doi:10.1016/j.eswa.2012.08.010

Liu, Y., Huang, Y., Luo, Y., \& Zhao, Y. (2012). How does justice matter in achieving buyer-supplier relationship performance? Journal of Operations Management, 30(5), 355-367. doi:http://dx.doi.org/10.1016/i.jom.2012.03.003

Locander, D. A., Mulki, J. P., \& Weinberg, F. J. (2014). How Do Salespeople Make Decisions? The Role of Emotions and Deliberation on Adaptive Selling, and the Moderating Role of Intuition. Psychology \& Marketing, 31(6), 387-403. doi:10.1002/mar.20702

Locander, D. A., Weinberg, F. J., Mulki, J. P., \& Locander, W. B. (2015). Salesperson lone wolf tendencies: The roles of social comparison and mentoring in a mediated model of performance. Journal of Marketing Theory and Practice, 23(4), 351-369. doi:10.1080/10696679.2015.1049680

Loveland, J. M., Lounsbury, J. W., Park, S.-H., \& Jackson, D. W. (2015). Are salespeople born or made? Biology, personality, and the career satisfaction of salespeople. Journal of Business \& Industrial Marketing, 30(2), 233-240. doi:10.1108/JBIM-12-2012-0257 
Lussier, B., Grégoire, Y., \& Vachon, M.-A. (2017). The role of humor usage on creativity, trust and performance in business relationships: An analysis of the salesperson-customer dyad. Industrial Marketing Management, 65, 168-181. doi:10.1016/j.indmarman.2017.03.012

Major, D. A., Turner, J. E., \& Fletcher, T. D. (2006). Linking Proactive Personality and the Big Five to Motivation to learn and development activity. Journal of Applied Psychology, 91(4), 927-935.

Malek, S. L., Sarin, S., \& Jaworski, B. J. (2018). Sales management control systems: Review, synthesis, and directions for future exploration. Journal of Personal Selling \& Sales Management, 38(1), 30-55. doi:10.1080/08853134.2017.1407660

Mallin, M. L., Gammoh, B. S., Pullins, E. B., \& Johnson, C. M. (2017). A new perspective of salesperson motivation and salesforce outcomes: The mediating role of salesperson-brand identification. Journal of Marketing Theory and Practice, 25(4), 357-374. doi:10.1080/10696679.2017.1345597

Mallin, M. L., \& Mayo, M. (2006). Why did I lose? A conservation of the resources and view of salesperson failure attributions. Journal of Personal Selling \& Sales Management, 26(4), 345-357.

Martin-Martin, A., Orduna-Malea, E., Harzing, A.-W., \& Delgado López-Cózar, E. (2017). Can we use Google Scholar to identify highly-cited documents? Journal of Informetrics, 11(1), 152-163. doi:https://doi.org/10.1016/i.joi.2016.11.008

Mayo, M., \& Mallin, M. L. (2010). The impact of sales failure on attributions made by "resourcechallenged" and "resource-secure" salespeople. Journal of Marketing Theory and Practice, 18(3), 233247. doi:10.2753/MTP1069-6679180302

McGowan, P. (2018). The impact of effectuation on small firm buying decisions. IMP Journal, 12(3), 444-459.

Meredith, J. (1993). Theory building through conceptual methods. International Journal of Operations \& Production Management, 13(5), 3-11.

Miao, C., \& Evans, K. (2013). The interactive effects of sales control systems on salesperson performance: a job demands-resources perspective. Journal of the Academy of Marketing Science, 41(1), 73-90. doi:10.1007/s11747-012-0315-4

Morris, M. H., LaForge, R. W., \& Allen, J. A. (1994). Salesperson failure: Definition, determinants, and outcomes. Journal of Personal Selling \& Sales Management, 14(1), 1-15.

Mulki, J. P., Jaramillo, F., \& Locander, W. B. (2006). Effects of Ethical Climate and Supervisory Trust on Salesperson'S Job Attitudes and Intentions to Quit. Journal of Personal Selling \& Sales Management, 26(1), 19-26. doi:10.2753/pss0885-3134260102

Mulki, J. P., Locander, W. B., Marshall, G. W., Harris, E. G., \& Hensel, J. (2008). Workplace Isolation, Salesperson Commitment, and Job Performance. Journal of Personal Selling \& Sales Management, 28(1), 67-78. doi:10.2753/pss0885-3134280105

Murphy, W. H., \& Li, N. (2012). A multi-nation study of sales manager effectiveness with global implications. Industrial Marketing Management, 41(7), 1152-1163. doi:10.1016/j.indmarman.2012.06.012

The new SME definition. (2016). Retrieved from https://ec.europa.eu/digital-singlemarket/en/news/new-sme-definition-user-guide-and-model-declaration 
Paik, S.-K. (2011). Supply Management in Small and Medium-Sized Enterprises: Role of SME Size. Supply Chain Forum: International Journal, 12(3), 10-21.

Panagopoulos, N. G., \& Avlonitis, G. J. (2010). Performance implications of sales strategy: The moderating effects of leadership and environment. International Journal of Research in Marketing, 27(1), 46-57. doi:http://dx.doi.org/10.1016/j.ijresmar.2009.11.001

Piercy, N. F., Cravens, D. W., \& Lane, N. (2014). Sales manager behavior-based control and salesperson performance: The effects of manager control competencies and organizational citizenship behavior. Journal of Marketing Theory and Practice, 20(1), 7-22. doi:10.2753/mtp1069-6679200101

Piercy, N. F., \& Garry, T. (2010). Evolution of strategic sales organizations in business-to-business marketing. Journal of Business \& Industrial Marketing, 25(5), 349-359. doi:10.1108/08858621011058115

Plank, Reid, Koppitsch, \& Meyer. (2018). The sales manager as a unit of analysis: a review and directions for future research. Journal of Personal Selling \& Sales Management, 38(1), 78-91.

Powers, T. L., DeCarlo, T. E., \& Gupte, G. (2010). An Update on the Status of Sales Management Training. Journal of Personal Selling \& Sales Management, 30(4), 319-326.

Powers, T. L., Jennings, J. A. C., \& DeCarlo, T. E. (2014). An assessment of needed sales management skills. Journal of Personal Selling \& Sales Management, 34(3), 206-222. doi:10.1080/08853134.2014.890900

Pullins, E. B., Timonen, H., Kaski, T., \& Holopainen, M. (2017). An Investigation of the Theory Practice Gap in Professional Sales. Journal of Marketing Theory \& Practice, 25(1), 17-38. doi:10.1080/10696679.2016.1236665

Rackham, N. (1988). SPIN selling: New York : McGraw-Hill.

Randall, E. J., \& Randall, C. H. (2001). A current review of hiring techniques for sales personnel: The first step in the sales management process. Journal of Marketing Theory and Practice, 9(2), 70-83. doi:10.1080/10696679.2001.11501892

Reid, D. A., Plank, R. E., Peterson, R. M., \& Rich, G. A. (2017). Examining the use of sales force management practices. Journal of Business \& Industrial Marketing, 32(7), 974-986. doi:10.1108/jbim02-2016-0040

Reynolds, P., Bosma, N., Autio, E., Hunt, S., De Bono, N., Servais, I., . . Chin, N. (2005). Global Entrepreneurship Monitor: Data Collection Design and Implementation 1998-2003. Small Business Economics, 24(3), 205-231. doi:10.1007/s11187-005-1980-1

Richardson, R. (1999). Measuring the impact of turnover on sales. Journal of Personal Selling \& Sales Management, 19(4), 53-66.

Rosenbloom, B. (2007). Multi-channel strategy in business-to-business markets: Prospects and problems. Industrial Marketing Management, 36, 4-9. doi:10.1016/j.indmarman.2006.06.010

Sager, J. K., Dubinsky, A. J., Wilson, P. H., \& Shao, C. (2014). Factors influencing the impact of sales training: Test of a model. International Journal of Marketing Studies, 6(1), 1. 
Saks, A. M., \& Gruman, J. A. (2014). Making organizations more effective through organizational socialization. Journal of Organizational Effectiveness: People and Performance, 1(3), 261-280.

Saxe, R., \& Weitz, B. A. (1982). The SOCO Scale: A Measure of the Customer Orientation of Salespeople. Journal of Marketing Research (JMR), 19(3), 343-351.

Schwarzmüller, T., Brosi, P., Duman, D., \& Welpe, I. M. (2018). How does the digital transformation affect organizations? Key themes of change in work design and leadership. Management Revue, 29(2), 114-138. doi:10.5771/0935-9915-2018-2-114

Schwepker, C. H., \& Good, D. J. (2012). Sales quotas: Unintended consequences on trust in organization, customer-oriented selling, and sales performance. Journal of Marketing Theory and Practice, 20(4), 437-452.

Sharma, A. (2007). The Metrics of Relationships. Journal of Relationship Marketing, 6(2), 33-50. doi:10.1300/J366v06n02_04

Sharma, A., \& Evanschitzky, H. (2016). Returns on key accounts: Do the results justify the expenditures? Journal of Business \& Industrial Marketing, 31(2), 174-182. doi:10.1108/jbim-11-20140234

Sharma, A., \& Mehrotra, A. (2007). Choosing an optimal channel mix in multichannel environments. Industrial Marketing Management, 36(1), 21-28. doi:10.1016/j.indmarman.2006.06.012

Singh, V. L., Manrai, A. K., \& Manrai, L. A. (2015). Sales training: A state of the art and contemporary review. Journal of Economics, Finance and Administrative Science, 20(38), 54-71. doi:10.1016/j.jefas.2015.01.001

Spillecke, S. B., \& Brettel, M. (2013). The impact of sales management controls on the entrepreneurial orientation of the sales department. European Management Journal, 31(4), 410-422. doi:10.1016/j.emj.2012.07.002

Steward, M. D., Hutt, M. D., Walker, B. A., \& Kumar, A. (2009). Role identity and attributions of highperforming salespeople. Journal of Business \& Industrial Marketing, 24(7), 463-473. doi:10.1108/08858620910986703

Stewart, J. S., Oliver, E. G., Cravens, K. S., \& Oishi, S. (2017). Managing millennials: Embracing generational differences. Business Horizons, 60(1), 45-54. doi:https://doi.org/10.1016/j.bushor.2016.08.011

Stich, J.-F., Tarafdar, M., \& Cooper, C. L. (2018). Electronic communication in the workplace: boon or bane? Journal of Organizational Effectiveness: People and Performance, 5(1), 98-106. doi:10.1108/JOEPP-05-2017-0046

Teas, R. K., \& McElroy, J. C. (1986). Causal attributions and expectancy estimates: A framework for understanding the dynamics of salesforce motivation. Journal of Marketing, 50(1), 75-86. doi:Doi $10.2307 / 1251280$

Terho, H., Eggert, A., Haas, A., \& Ulaga, W. (2015). How sales strategy translates into performance: The role of salesperson customer orientation and value-based selling. Industrial Marketing Management, 45, 12-21. doi:https://doi.org/10.1016/i.indmarman.2015.02.017 
Thaichon, P., Surachartkumtonkun, J., Quach, S., Weaven, S., \& Palmatier, R. W. (2018). Hybrid sales structures in the age of e-commerce. Journal of Personal Selling \& Sales Management, 38(3), 277-302. doi:10.1080/08853134.2018.1441718

Tranfield, D., Denyer, D., \& Smart, P. (2003). Towards a methodology for developing evidenceinformed management knowledge by means of systematic review. British journal of management, 14(3), 207-222.

Verbeke, W., \& Bagozzi, R. P. (2000). Sales Call Anxiety: Exploring What It Means When Fear Rules a Sales Encounter. Journal of Marketing, 64(3), 88-101.

Wang, S., \& Huff, L. C. (2007). Explaining buyers' responses to sellers' violation of trust. European Journal of Marketing, 41(9/10), 1033-1052. doi:10.1108/03090560710773336

Webb, K. L., \& Lambe, C. J. (2007). Internal multi-channel conflict: An exploratory investigation and conceptual framework. Industrial Marketing Management, 36(1), 29-43. doi:http://dx.doi.org/10.1016/j.indmarman.2006.06.013

Weitz, B. A., Sujan, H., \& Sujan, M. (1986). Knowledge, motivation, and adaptive behavior: A framework for improving selling effectiveness. Journal of Marketing, 50(4), 174-191.

Widmier, S., \& Jackson Jr, D. W. (2002). Examining the effects of service failure, customer compensation, and fault on customer satisfaction with salespeople. Journal of Marketing Theory \& Practice, 10(1), 63-74.

Wilson, H., \& Daniel, E. (2007). The multi-channel challenge: A dynamic capability approach. Industrial Marketing Management, 36(1), 10-20. doi:10.1016/j.indmarman.2006.06.015

Wilson, K., \& Woodburn, D. (2014). The impact of organisational context on the failure of key and strategic account management programmes. Journal of Business \& Industrial Marketing, 29(5), 353363. doi:10.1108/jbim-03-2013-0061

Yurova, Y., Rippé, C. B., Weisfeld-Spolter, S., Sussan, F., \& Arndt, A. (2016). Not all adaptive selling to omni-consumers is influential: The moderating effect of product type. Journal of Retailing and Consumer Services. doi:10.1016/j.jretconser.2016.01.009 